\title{
Crowding out in the Dutch labour market for R\&D workers
}

Citation for published version (APA):

Marey, P. S. (2002). Crowding out in the Dutch labour market for $R \& D$ workers. Researchcentrum voor Onderwijs en Arbeidsmarkt, Faculteit der Economische Wetenschappen. ROA Reports No. 6E https://doi.org/10.26481/umarep.200206E

Document status and date:

Published: 01/01/2002

DOI:

10.26481/umarep.200206E

Document Version:

Publisher's PDF, also known as Version of record

\section{Please check the document version of this publication:}

- A submitted manuscript is the version of the article upon submission and before peer-review. There can be important differences between the submitted version and the official published version of record.

People interested in the research are advised to contact the author for the final version of the publication, or visit the DOI to the publisher's website.

- The final author version and the galley proof are versions of the publication after peer review.

- The final published version features the final layout of the paper including the volume, issue and page numbers.

Link to publication

\footnotetext{
General rights rights.

- You may freely distribute the URL identifying the publication in the public portal. please follow below link for the End User Agreement:

www.umlib.nl/taverne-license

Take down policy

If you believe that this document breaches copyright please contact us at:

repository@maastrichtuniversity.nl

providing details and we will investigate your claim.
}

Copyright and moral rights for the publications made accessible in the public portal are retained by the authors and/or other copyright owners and it is a condition of accessing publications that users recognise and abide by the legal requirements associated with these

- Users may download and print one copy of any publication from the public portal for the purpose of private study or research.

- You may not further distribute the material or use it for any profit-making activity or commercial gain

If the publication is distributed under the terms of Article $25 \mathrm{fa}$ of the Dutch Copyright Act, indicated by the "Taverne" license above, 


\section{Crowding out in the Dutch labour market for R\&D workers}

ROA-R-2002/6E

Philip Marey

Research Centre for Education and the Labour Market

Faculty of Economics and Business Administration Maastricht University

Maastricht, May 2002 
ISBN 90-5321-332-5

sec01.384.doc 


\section{Contents}

Pages

Voorwoord (Preface in Dutch)

Samenvatting (Summary in Dutch) iii

Abstract

1 Introduction 1

2 Educational backgrounds of R\&D-workers in the Netherlands 7

2.1 Educational backgrounds of R\&D-workers in sectors of the Dutch $\begin{array}{ll}\text { economy } & 7\end{array}$

2.2 Technical university graduates in sectors of the Dutch economy 8

3 Foreign R\&D-workers in the Netherlands 11

4 The crowding-out-model 13

$\begin{array}{ll}4.1 \text { Crowding-out-elasticities } & 13\end{array}$

4.2 Long-term and short-term elasticities in an equilibrium correction mechanism

4.3 Estimation and model selection $\quad 15$

$\begin{array}{ll}4.4 & \text { Implied cross-elasticities } \\ \end{array}$

5 Estimation results $\quad 19$

$\begin{array}{ll}5.1 \text { Metal industries } & 19\end{array}$

$\begin{array}{ll}5.2 \text { Chemical industries } & 20\end{array}$

$\begin{array}{lll}5.3 & \text { Food and beverage industry } & 21\end{array}$

5.4 Transport, communication and commercial services 22

$\begin{array}{lll}5.5 & \text { Agriculture and fisheries } & 23\end{array}$

5.6 Research enterprises $\quad 25$

$\begin{array}{lll}5.7 & \text { Other industries } & 25\end{array}$

$\begin{array}{ll}5.8 \text { Universities } & 26\end{array}$

5.9 Government institutions $\quad 27$

$\begin{array}{ll}5.10 \text { Private non-profit organisations } & 29\end{array}$

6 Crowding-out-effects of sectoral R\&D-expenditures 31

7 Conclusion $\quad 35$

$\begin{array}{ll}\text { References } & 37\end{array}$ 



\section{Voorwoord (Preface in Dutch)}

Innovatie is cruciaal voor economische groei. Voor het verrichten van R\&D-activiteiten is echter slechts een beperkte groep kenniswerkers beschikbaar. Een toename van R\&D-activiteiten in bepaalde sectoren kan daardoor negatieve gevolgen hebben voor andere sectoren. Empirisch onderzoek naar dergelijke crowding-out-effecten op de Nederlandse arbeidsmarkt voor kenniswerkers kan derhalve een bijdrage leveren aan de vormgeving van het Nederlandse innovatiebeleid. Enerzijds kan de overheid een bijdrage leveren aan het opvangen van crowding-out-effecten en anderzijds is het van belang rekening te houden met mogelijke crowding-out-effecten die onbedoeld uitgaan van beleidsmaatregelen die erop gericht zijn om innovatieve activiteiten te stimuleren.

Dit rapport is geschreven in opdracht van de directie Algemene Economische Politiek van het Ministerie van Economische Zaken. Het onderzoek is uitgevoerd door Philip Marey. Verder is aan het onderzoek meegewerkt door Sander Dijksman. De auteur dankt de leden van de begeleidingscommissie, Guido Biessen, Eddy Adang, Heidi Buijtels, Jessika Kersting en Stephan Raes voor hun inhoudelijke bijdrage aan de totstandkoming van het rapport. 


\section{Samenvatting (Summary in Dutch)}

Voor het uitvoeren van R\&D-activiteiten is slechts een beperkte groep kenniswerkers beschikbaar. Dit betekent dat een intensivering van R\&D-activiteiten in bepaalde sectoren van de Nederlandse economie via de arbeidsmarkt voor kenniswerkers ook gevolgen heeft voor de overige sectoren. Vanwege de arbeidsmobiliteit tussen sectoren, zal een loonstijging in de ene sector kenniswerkers aantrekken uit de andere sector. Om de uitstroom van kenniswerkers te stoppen zal dan ook de andere sector de lonen moeten verhogen. Een toename van de R\&D-uitgaven in een sector verhoogt derhalve het aantal kenniswerkers en de lonen in de eigen sector, maar verlaagt het aantal kenniswerkers en verhoogt de lonen in andere sectoren (zie tabel 1). Veranderingen in de sectorale allocatie van kenniswerkers kan gevolgen hebben voor de lange-termijn-groeivoet van de economie als niet alle sectoren dezelfde bijdrage aan deze groeivoet leveren. Voor innovatiebeleid is het van belang rekening te houden met deze crowding-out-effecten op de arbeidsmarkt voor kenniswerkers. In de eerste plaats kan de overheid randvoorwaarden scheppen waardoor crowding-out-effecten zoveel mogelijk kunnen worden opgevangen. In de tweede plaats kunnen bestaande beleidsmaatregelen zelf ook onbedoeld crowding-out-effecten versterken.

Tabel 1

Effecten van sectorale R\&D-uitgaven op kennisactiviteiten

\begin{tabular}{lll}
\hline & hoeveelheid kennisactiviteiten & prijs van kennisactiviteiten \\
\hline eigen sector & toename & toename \\
andere sectoren & afname & toename \\
\hline
\end{tabular}

Hierbij gaat het niet alleen om afwegingen tussen verschillende sectoren van het bedrijfsleven, maar ook tussen het bedrijfsleven enerzijds en overheidsinstellingen en universiteiten anderzijds. In het bedrijfsleven ligt de nadruk op toegepast onderzoek, terwijl in overheidsinstellingen en vooral universiteiten meer aan fundamenteel onderzoek gedaan wordt. Het stimuleren van R\&D in het bedrijfsleven zou dan een negatief effect kunnen hebben op de omvang van het fundamenteel onderzoek. Met name op de lange termijn kan dit nadelige effecten hebben. Anderzijds kan het stimuleren van R\&D in overheidsinstellingen en universiteiten leiden tot zowel het onttrekken van werknemers aan het bedrijfsleven als het opdrijven van de lonen van kenniswerkers in het bedrijfsleven.

De omvang van de crowding-out-effecten hangt af van de mate van similariteit van de opleidingsachtergronden van kenniswerkers in de verschillende sectoren, alsmede de mogelijkheden om Nederlandse kenniswerkers te vervangen door buitenlandse. Naarmate de gevraagde opleidingsachtergronden in twee sectoren meer op elkaar lijken, zullen de crowding-out-effecten een grotere omvang hebben. Uit onderzoek voor de Verenigde Staten blijkt dat federale R\&D-uitgaven een opwaarts effect 
hebben op de lonen van ingenieurs vliegtuigbouwkunde, werktuigbouwkunde, materiaalkunde en electrotechniek. Dit zijn de typische defensie-industrie beroepen, waar tenslotte het merendeel van de federale R\&D-uitgaven aan wordt gespendeerd. ${ }^{1}$ Hiermee wordt niet alleen de R\&D in de sector waarin de speerpunttechnologie wordt ontwikkeld duurder, maar ook de R\&D in enkele andere sectoren. Bovendien worden kenniswerkers aan die andere sectoren onttrokken. De Amerikaanse overheid staat daarmee voor een trade-off tussen het direct stimuleren van de ene sector en het indirect afremmen van andere sectoren. In geval van crowdingout-effecten tussen bedrijfsleven en publieke sfeer kan er een dempend effect uitgaan van de heterogeniteit van preferenties van werknemers: de voorkeur voor het verrichten van fundamenteel onderzoek boven toegepast onderzoek kan ertoe leiden dat sommige mensen bereid zijn een aanzienlijk loonverschil te accepteren. Uit een onderzoek onder post-doctorale biologen in de Verenigde Staten blijkt dat deze 'compensating wage differentials' kunnen oplopen tot $25 \%{ }^{2}$ De tweede verklaring van de relatieve omvang van crowding-out-effecten houdt verband met de internationale mobiliteit van kenniswerkers. Sectoren waarin Nederlandse kenniswerkers makkelijker te vervangen zijn door buitenlandse kenniswerkers, zullen crowding-out-effecten beter kunnen opvangen dan sectoren waarin die substitutie moeilijker is.

De rol die de Nederlandse overheid speelt in de financiering van private R\&Duitgaven wordt geillustreerd aan de hand van tabel 2, waarin de sectorale verdeling van Nederlands innovatiebeleidsgeld met betrekking tot technologiestimuleringsmaatregelen is weergegeven. Hieruit blijkt dat de sectorale verdeling van Nederlands innovatiebeleidsgeld met betrekking tot technologiestimuleringsmaatregelen verschilt van de sectorale verdeling van de totale R\&D-uitgaven. Daarbij moet worden aangetekend dat het hier slechts om een deel van het innovatiebeleidsinstrumentarium gaat. Bovendien kunnen innovaties in bepaalde sectoren ook een uitstraling naar de gehele economie hebben ('enabling technologies'). Verder kan innovatiebeleid er ook op gericht zijn de aansluiting tussen de publieke en private kennisinfrastructuur te stimuleren.

De twee belangrijkste conclusies die uit tabel 2 getrokken kunnen worden zijn als volgt. In de eerste plaats kunnen generieke maatregelen in bepaalde sectoren sterker neerslaan dan in andere sectoren. Overheidsmaatregelen die bedoeld zijn om R\&D-uitgaven in het algemeen of bepaalde technologie-gebieden in het bijzonder te stimuleren, kunnen er in de praktijk toe leiden dat innovatiebeleidsgeld de R\&Duitgaven in de ene sector sterker doet toenemen dan in de andere sector. Hiermee kan onbedoeld een bijdrage aan crowding-out-effecten worden geleverd.

1. Goolsbee (1998).

2. Stern (1999).

iv 


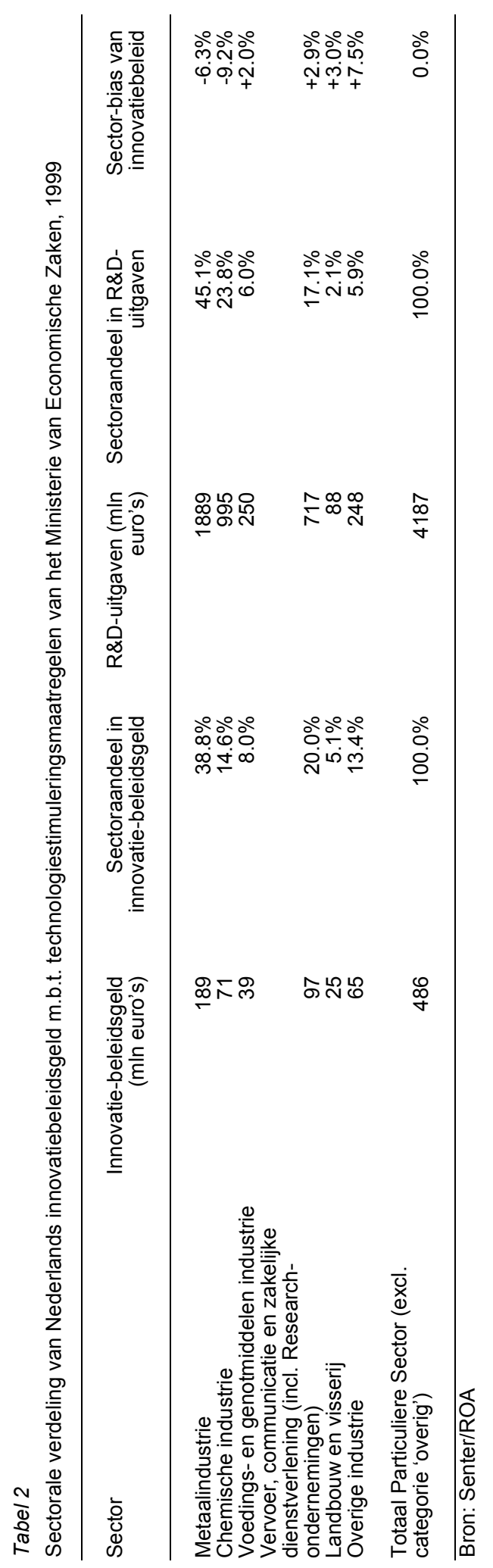


In de tweede plaats, blijken R\&D-uitgaven in het bedrijfsleven vooral uit eigen middelen of op de kapitaalmarkt gefinancierd te worden en slechts in beperkte mate uit publieke middelen. De overheid heeft derhalve slechts een beperkte invloed op de groei van R\&D-uitgaven in het bedrijfsleven ${ }^{3}$, maar des te meer op de groei van R\&D-uitgaven in de publieke sector.

In dit rapport wordt verslag gedaan van de resultaten van een empirisch onderzoek naar crowding-out-effecten op de Nederlandse arbeidsmarkt voor kenniswerkers. Voor het onderzoek is een econometrisch model voor crowding out ontwikkeld, gebaseerd op coïntegratie-analyse van tijdreeksen uit de R\&D-enquête van het CBS. Hierbij wordt onderscheid gemaakt tussen korte-termijn-elasticiteiten en langetermijn-elasticiteiten zodat de dynamiek op de arbeidsmarkt voor kenniswerkers beter in beeld gebracht wordt.

In het model komen mogelijke effecten van R\&D-activiteiten in de publieke sfeer op het bedrijfsleven tot uiting in de crowding-out-effecten van overheidsinstellingen en universiteiten op verschillende sectoren van het bedrijfsleven. De overige crowdingout-effecten geven de gevolgen weer van private R\&D-activiteiten op andere sectoren van het bedrijfsleven en de publieke sector. Hierbij wordt geen onderscheid gemaakt tussen publieke en private financiering van R\&D-uitgaven in het bedrijfsleven. Deze crowding-out-effecten kunnen dus zowel veroorzaakt worden door R\&Duitgaven die uit eigen middelen of op de kapitaalmarkt gefinancierd zijn als door R\&D-uitgaven die uit publieke middelen komen.

De schattingsresultaten in dit rapport (samengevat in tabel 3) tonen aan dat de metaalindustrie, de chemische industrie, de voedings- en genotmiddelenindustrie en de sector vervoer, communicatie en zakelijke dienstverlening last hebben van crowding out door overheidsinstellingen en universiteiten. Andersom heeft de publieke sector geen last van crowding out, noch vanuit het bedrijfsleven, noch binnen de publieke sector zelf, tussen overheidsinstellingen en universiteiten. Hiervoor zijn twee verklaringen te geven. De eerste houdt verband met het meer dan gemiddelde percentage buitenlandse kenniswerkers in de publieke sector: blijkbaar worden personeelstekorten aangevuld via de internationale arbeidsmarkt voor kenniswerkers. De tweede verklaring is de voorkeur voor fundamenteel onderzoek van een groot aantal kenniswerkers. Het gevolg is dat het stimuleren van private R\&D geen crowding-out-effecten lijkt te hebben op de publieke R\&D. In dit opzicht hoeft er dus geen trade-off gemaakt te worden door de overheid. Hierbij moet worden opgemerkt dat door de herdefiniëring van universitaire $R \& D$ de econometrische analyse beperkt is tot de periode 1973-1993.

3. Het effect van overheidsmaatregelen op private R\&D is overigens groter dan blijkt uit de bijdrage aan private R\&D-uitgaven, wegens multiplier-effecten ("bang for the buck") en de institutionele rol van de overheid in het scheppen van een omgeving die innovatie stimuleert. 
Crowding out binnen het bedrijfsleven vindt plaats in een aantal bedrijfstakken. De metaalindustrie en de chemische industrie hebben crowding-out-effecten op elkaar, maar ook op de voedings- en genotmiddelenindustrie en de sector vervoer, communicatie en zakelijke dienstverlening. Een belangrijke rol in deze processen spelen natuurkundigen, chemici, elektrotechnisch ingenieurs en werktuigbouwkundig ingenieurs. De landbouw en visserij hebben crowding-out-effecten op de chemische industrie, hierbij gaat het met name om WO-ers natuurwetenschappen en HBO-ers laboratorium. Tenslotte hebben researchondernemingen last van crowding-out-effecten van particuliere non-profit organisaties. Hierbij spelen zowel natuurwetenschappers als economen en sociologen een rol.

Tabel 3

Crowding-out-effecten op de Nederlandse arbeidsmarkt voor kenniswerkers, 1973-1993

\begin{tabular}{|c|c|}
\hline Sector & Crowding out door: \\
\hline Metaalindustrie & $\begin{array}{l}\text { Chemische industrie } \\
\text { Universiteiten } \\
\text { Overheidsinstellingen }\end{array}$ \\
\hline Chemische industrie & $\begin{array}{l}\text { Metaalindustrie } \\
\text { Landbouw en visserij } \\
\text { Universiteiten } \\
\text { Overheidsinstellingen }\end{array}$ \\
\hline Voedings- en genotmiddelenindustrie & $\begin{array}{l}\text { Metaalindustrie } \\
\text { Chemische industrie } \\
\text { Universiteiten } \\
\text { Overheidsinstellingen }\end{array}$ \\
\hline Vervoer, communicatie en zakelijke dienstverlening & $\begin{array}{l}\text { Metaalindustrie } \\
\text { Chemische industrie } \\
\text { Universiteiten } \\
\text { Overheidsinstellingen }\end{array}$ \\
\hline Landbouw en visserij & - \\
\hline Researchondernemingen & Particuliere non-profit organisaties \\
\hline Overige industrie & - \\
\hline Universiteiten & - \\
\hline Overheidsinstellingen & - \\
\hline Particuliere non-profit organisaties & - \\
\hline
\end{tabular}

Hoewel het Nederlandse innovatiebeleid in principe generiek is, lijkt de asymmetrische neerslag van innovatiebeleidsgeld met betrekking tot technologiestimuleringsmaatregelen in het voordeel van landbouw en visserij en in het nadeel van de chemische industrie (tabel 2) tot crowding-out-effecten te kunnen leiden waarmee rekening gehouden moet worden. Dit geldt overigens evenzeer voor R\&D-uitgaven in de landbouw en visserij die door deze sector zelf uit eigen middelen of op de kapitaalmarkt gefinancierd worden. Aangezien de econometrische analyse betrekking heeft op de periode 1973-1993, kunnen echter geen harde uitspraken worden gedaan over de effecten van de allocatie van innovatiebeleidsgeld in 1999. 
Desalniettemin suggereren de empirische resultaten voor 1973-1993 dat een sector bias in het voordeel van de voedings- en genotmiddelenindustrie, de sector vervoer, communicatie en zakelijke dienstverlening en de overige industrie (tabel 2) waarschijnlijk niet tot crowding-out-effecten zal leiden.

De resultaten in dit rapport benadrukken de betekenis die internationale arbeidsmobiliteit van R\&D-werkers kan spelen in het opvangen van crowding-out-effecten tussen sectoren van de Nederlandse economie. Een aantrekkelijk onderzoeksklimaat stimuleert niet alleen de instroom van buitenlandse onderzoekers, maar heeft ook een remmende werking op de uitstroom van Nederlandse R\&D-werkers. Momenteel spelen buitenlandse kenniswerkers vooral een rol in de publieke sector. Samen met de onderzoeksvoorkeuren van Nederlandse kenniswerkers verklaart dit het ontbreken van crowding-out-effecten in de publieke sector. Het stimuleren van private R\&D lijkt derhalve geen negatieve gevolgen te hebben voor publieke R\&D, zolang overheidsinstellingen en universiteiten voldoende buitenlandse kenniswerkers weten aan te trekken. Beleidsmaatregelen die erop gericht zijn de instroom van buitenlandse kenniswerkers in het bedrijfsleven te stimuleren zouden een belangrijke bijdrage kunnen leveren in het opvangen van de crowding-out-effecten die nu in bepaalde sectoren optreden. 


\begin{abstract}
Increases in R\&D-activities in certain sectors of the economy may have negative effects on other sectors through the labour market for R\&D-workers. Since only a limited amount of R\&D-workers is available to perform R\&D-activities, crowding-outeffects may occur. The resulting changes in the sectoral allocation of R\&D-workers may have an effect on the long-term growth rate of the economy if sectors differ in their contribution to this growth rate. Innovation policy can play a role in creating conditions which dampen these crowding-out-effects. At the same time, policy measures aimed at increasing R\&D in general or certain technologies in particular, may in practice have asymmetric effects on the R\&D-expenditures of different sectors, which may contribute to crowding-out-effects.
\end{abstract}

Crowding-out-effects may occur between the public and the private sector, but also between different industries in the private sector. In this report, the effect of public sector R\&D on private sector R\&D can be seen from the crowding-out-effects of government institutions and universities on industries in the private sector. The effect of publicly-financed R\&D in the private sector can be inferred from the crowding-outeffects between industries within the private sector. These crowding-out-effects also reflect crowding out caused by privately-financed R\&D.

The empirical results for the Netherlands in this report show that government institutions and universities crowd out the metal industries, chemical industries, the food and beverage industry and the transport, communication and commercial services sector. At the same time, the public sector does not seem to suffer from crowding out, neither by the private sector, nor within the public sector itself, between government institutions and universities. The above average use of foreign R\&Dworkers in the public sector and individual preferences for basic research may explain the absence of crowding-out-effects. As a result, policy measures to stimulate private R\&D do not seem to have crowding-out-effects on public R\&D. Hence policy makers do not face a trade-off in this respect.

Crowding out within the private sector occurs in a number of industries. The metal industries and chemical industries crowd out each other, but also the food and beverage industry and the transport, communication and commercial services sector. The agriculture and fisheries sector crowds out the chemical industries and private non-profit organisations crowd out research enterprises.

Although Dutch innovation policy is generic in nature, the asymmetry of current Dutch innovation policy expenditure in favour of agriculture and fisheries and against chemical industries could lead to crowding-out-effects, which have to be taken into account. On the other hand, a sector bias in favour of the food and beverage industry, the transport, communication and commercial services sector and the other industries will probably not cause crowding-out-effects. The results suggest that policy measures that increase the inflow of foreign R\&D-workers both to the public and the private sector may be helpful in alleviating crowding-out-effects. 



\section{Introduction}

Innovation is crucial for economic growth. However, there is only a limited amount of knowledge workers available to perform R\&D-activities. An increase in R\&D-activities in certain sectors of the economy may therefore have negative effects on R\&D in other sectors: crowding-out-effects may occur via the labour market for R\&Dworkers. Because of the labour mobility between sectors, a wage increase in one sector may attract R\&D-workers from another sector. In order to stem the outflow of R\&D-workers the other sector will also have to raise its wages. An increase in R\&Dexpenditure in one sector therefore raises the number of R\&D-workers and their wages in the own sector, but lowers the number of R\&D-workers and pushes up the wages in the other sector (see table 1.1).

Table 1.1

Effects of sectoral R\&D-expenditures on R\&D-activities

\begin{tabular}{lll}
\hline & Amount of R\&D-activities & Price of R\&D-activities \\
\hline Own sector & increase & increase \\
Other sectors & decrease & increase \\
\hline
\end{tabular}

Public support for R\&D can be distinguished between increasing R\&D in the public sector (government institutions and universities) and financial support for R\&D in the private sector through tax deductions, subsidies, procurements, grants etc. Crowding out of private sector R\&D by public sector R\&D is usually analysed in terms of R\&D expenditure. However, recent studies by Goolsbee (1998), van den Hove et al. (1998), Trajtenberg (2000) and Marey \& Borghans (2000) show that increases in R\&D expenditure also lead to increases in wages of R\&D-workers. As a result, increases in R\&D expenditure overestimate the actual increases in R\&D activities. Cornet (2001) provides estimates based on the aforementioned studies of the effectiveness of Dutch technology subsidies. In this report we will analyse crowding out in terms of R\&D activities instead of R\&D expenditures. For example, we will not estimate the effects of increases in public sector R\&D expenditure on private sector R\&D expenditure, but on private sector R\&D activities, measured in terms of employment.

David, Hall \& Toole (2000) review the econometric evidence on the effects of publicly-financed R\&D expenditure in the private sector. Studies at the level of industries or higher tend towards complementarity instead of substitution (crowding out) between publicly-financed R\&D-expenditure and privately-financed R\&Dexpenditure. However, these studies focus on the effect on R\&D expenditures instead of R\&D activities, hence the upward effect on wages has not been taken into account by these studies. This implies that the evidence in favour of complementarity should be discounted somewhat. Studies at the firm level and lower (lines of business, laboratories) show a mixed picture. For the US the evidence seems slightly 
in favour of substitution, whereas for other countries complementarity is found more often.

A recent study of 17 OECD-countries by Guellec \& van Pottelsberghe (2000) finds evidence of complementarity between publicly-financed R\&D expenditure in the private sector and privately-financed R\&D expenditure. However, if they correct their calculations to take into account the upward wage effects estimated by Goolsbee (1998), the effect of publicly-financed R\&D expenditure disappears. They also find that expenditure on R\&D performed in the public sector crowds out private sector R\&D expenditure. Especially, defence research seems to play an important role here, as it is less used by and diffused to the civilian private sector. Notice that the evidence for substitution will be even stronger, when upward pressure on wages is taken into account.

David \& Hall (2000) provide an analytical framework to capture both positive and negative spillover effects on R\&D activities (measured in terms of R\&D employment) in the public and private sector of public R\&D expenditure, which is distinguished between R\&D expenditure in the public sector and publicly-financed R\&D expenditure in the private sector. They conclude that crowding out of private sector $R \& D$-activities by public sector R\&D expenditure is more likely if the public R\&D sector is large, if the wage elasticity of the supply of R\&D-workers is small and if positive spillovers from the public to the private sector are small. Goolsbee (1998) finds that government R\&D expenditure crowds out R\&D activities (measured in hours worked) in the private sector by raising wages of scientists and engineers. Federal R\&D expenditure in the defence industry plays a major role.

In this report, the effect of public sector R\&D on private sector R\&D can be seen from the crowding-out-effects of government institutions and universities on industries in the private sector. The effect of publicly-financed R\&D in the private sector (table 1.2) can be inferred from the crowding-out-effects between industries within the private sector. These crowding-out-effects also reflect crowding out caused by privatelyfinanced R\&D.

Although the final outcome of R\&D policy is affected by the effect on overall R\&D input, another factor is the sectoral composition of R\&D inputs, because the contributions to long-term economic growth may differ between sectors. Innovation policy measures aimed at increasing R\&D in general or certain technologies in particular, may in practice exhibit a sector bias. Generic measures may have asymmetric effects on R\&D-expenditures between sectors. Sector biases may contribute to crowding out between different industries in the private sector. There is not only a possible trade-off for innovation policy between industries within the private sector, but also between the private sector and the public sector. In the private sector the emphasis of R\&D lies on applied research, while government institutions and universities are focused on basic research. Consequently increases in R\&D in the private sector may have a negative impact on the amount of basic research. Especially in the long run this might have negative effects. On the other 
hand, an intensification of R\&D in the public sector may lead to diverting R\&Dworkers from and raising wages in the private sector.

The role of innovation policy with respect to crowding-out-effects is twofold. In the first place, the government may play a role in alleviating crowding-out-effects. In the second place, policy measures that are aimed at stimulating innovation could unintentionally contribute to crowding-out-effects.

Although Dutch innovation policy is generic in principle, the effects on private R\&Dexpenditures may unintentionally exhibit a sector bias. The contribution of the Dutch government in financing private R\&D-expenditures is illustrated in table 1.2, which shows the distribution of Dutch innovation policy expenditure associated with technology stimulation measures between industries in the private sector and compares it with the distribution of total R\&D expenditure. A sector-neutral policy would imply that the two distributions are equal. Evidently, this is not the case in the Netherlands. The last column of table 1.2 shows a measure of sector bias, which is calculated by subtracting the sector share in R\&D-expenditure from the sector share in innovation policy expenditure. From table 1.2 it is clear that Dutch innovation policy expenditures associated with technology stimulation measures exhibit a bias against the metal industries and the chemical industries, favouring the food and beverage industry, transport, communication and commercial services, agriculture and fisheries and other industries. For example, unbiased innovation policy expenditures would imply that $(23.8 \% \times 486=) 115.7$ million euros are spent on the chemical industries and $(2.1 \% \times 486=) 10.2$ million euros on agriculture and fisheries. Hence chemical industries are receiving (115.7-71=) 44.7 million euros too few, while agriculture and fisheries are receiving (25-10.2=) 14.8 million euros too many. Unbiased innovation policy expenditures would imply an increase in R\&D-support for the chemical industries of $(100 \times 44.7 / 71=) 63 \%$ and a decrease in support for agriculture and fisheries of $(100 \times 14.8 / 25=) 59 \%$.

It should be noted that technology stimulation measures are only a part of the innovation policy instruments and that innovation in certain sectors also have an effect on the rest of the economy ('enabling technologies'). In addition, innovation policy can also be targeted at stimulating the connection between public and private knowledge infrastructure.

The two main conclusions that can be drawn from table 1.2 are as follows. In the first place, government policies that are aimed at increasing R\&D in general or certain technologies in particular may have asymmetric effects on sectoral R\&Dexpenditures. As a result, innovation policy measures could unintentionally contribute to crowding-out-effects. In the second place, private R\&D-expenditures are predominantly financed by firms internally or in the capital markets. Innovation policy expenditures - as far as related to technology stimulation measures - are about $12 \%$ of total R\&D-expenditures in the private sector. The government therefore has a 
limited influence on the growth of private R\&D-expenditures ${ }^{4}$, whereas the role in public sector R\&D is considerably larger.

The remainder of this report is organised as follows. In chapter 2 and 3 we take a look at the two main determinants of crowding out. In chapter 2 we look at the educational backgrounds of R\&D-workers in the various sectors of the Dutch economy. A high similarity of R\&D-workers in different sectors will enhance crowding-out-effects. Chapter 3 discusses the presence of foreign R\&D-workers in the Netherlands. The possibilities for international subsitution may dampen crowdingout-effects. In chapter 4 the crowding-out-model for the Dutch labour market for R\&D-workers is presented. The estimation results are discussed in chapter 5. In chapter 6 the crowding-out-effects found in chapter 5 are discussed from a policy perspective and chapter 7 concludes.

4. The impact of government policies on private R\&D is larger then appears from the contribution to private R\&D-expenditures, because of multiplier-effects ("bang for the buck") and the government's institutional role in creating an environment which is conducive to innovation. 


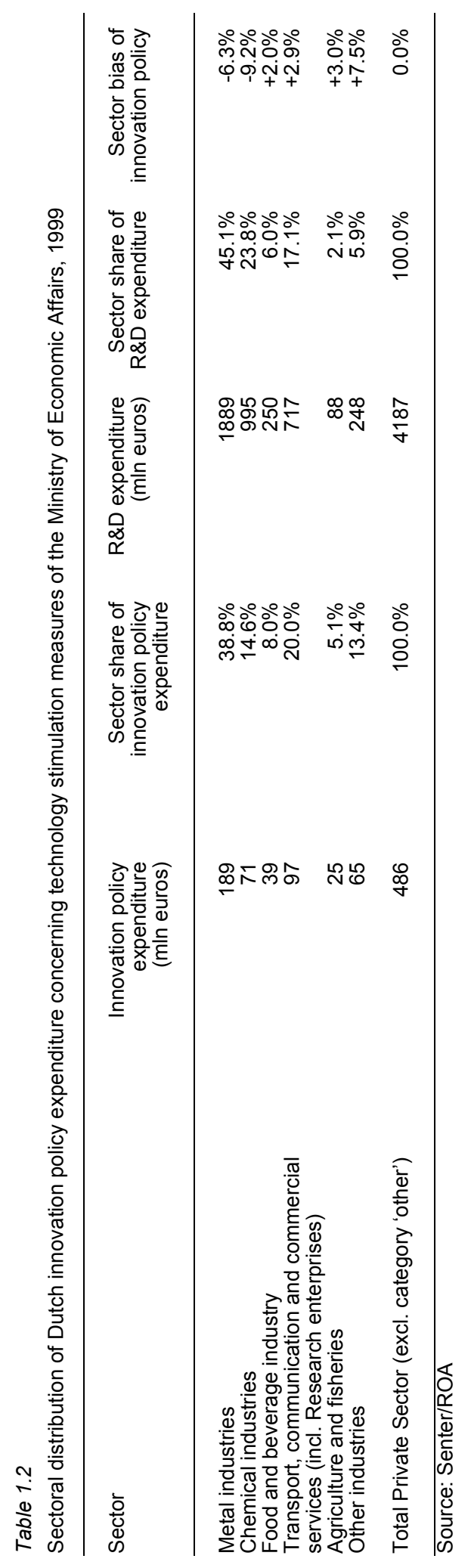





\section{Educational backgrounds of R\&D-workers in the Netherlands}

\subsection{Educational backgrounds of R\&D-workers in sectors of the Dutch economy}

The most obvious risk factor with respect to crowding out is the possible similarity in educational backgrounds of R\&D-workers in different sectors of the Dutch economy. A policy measure which is aimed at stimulating a certain technology will have an upward effect on the wages of R\&D-workers in the sector where this technology is developed, but indirectly also on the wages of R\&D-workers in other sectors with similar educational backgrounds. Empirical evidence for the United States (Goolsbee, 1998) shows that federal R\&D-expenditures have an upward effect on the wages of aeronautical engineers, mechanical engineers, metallurgical engineers and electrical engineers. These are the typical defence industry professions, where after all most of federal R\&D money is spent.

A higher similarity in the educational backgrounds of R\&D-workers between different sectors will lead to stronger crowding-out-effects. In case of crowding out between the private and the public sector, there may be a dampening effect from the heterogeneity of individual preferences of R\&D-workers: a researcher who prefers basic research above applied research may be willing to accept a substantial wage difference. Stern (1999) estimates that these compensating wage differentials may be as high as $25 \%$ for post-doctoral biologists in the United States.

Table 2.1 presents the educational backgrounds of workers with an R\&D-occupation in the Netherlands by economic sector. The data were obtained from and the Dutch Labour Force Survey (EBB) which is performed by Statistics Netherlands (CBS). In order to increase cell counts, the average numbers for the years 1997, 1998, 1999, 2000 were used to compute shares. The table shows the number of workers with an R\&D-occupation by type of education in the various sectors of the Dutch economy. Only types of education with a share of $10 \%$ or higher within a sector are displayed.

University-educated mathematicians and natural scientists play a crucial role in R\&D. They are the main performers of R\&D in the metal industries, chemical industries, research enterprises and government institutions, while they come in second in the food and beverage industry, transportation, communication and commercial services, and agriculture and fisheries. Their pervasive presence in R\&D-activities in a large number of sectors makes them a prime candidate as vehicle for crowding-outmechanisms.

Mechanical engineers account for a significant amount of R\&D in the metal industries and the food and beverage industry. Electrical engineers perform a considerable share of R\&D in the metal industries and other industries. As far as technical assistants in R\&D are concerned, HVE laboratory is important for both the chemical industries and agriculture and fisheries. 
Economists, MBAs and industrial engineers are significantly involved in R\&D in the food and beverage industry, transport, communication and commercial services, and research enterprises. Social scientists play a role in research enterprises and government institutions.

Table 2.1

Educational backgrounds of R\&D-workers in the Netherlands, by economic sector, 1997-2000

\begin{tabular}{|c|c|c|}
\hline Sector & Types of education & $\%$ share in sector \\
\hline Metal industries & $\begin{array}{l}\text { UE mathematics and natural sciences } \\
\text { UE mechanical engineering } \\
\text { UE electrical engineering } \\
\text { HVE mechanical engineering }\end{array}$ & $\begin{array}{l}21 \\
16 \\
11 \\
11\end{array}$ \\
\hline Chemical industries & $\begin{array}{l}\text { UE mathematics and natural sciences } \\
\text { HVE laboratory }\end{array}$ & $\begin{array}{l}35 \\
13\end{array}$ \\
\hline Food and beverage industry & $\begin{array}{l}\text { UE economics } \\
\text { UE mathematics and natural sciences } \\
\text { UE business administration and industrial } \\
\text { engineering } \\
\text { UE mechanical engineering }\end{array}$ & $\begin{array}{l}28 \\
16 \\
12 \\
10\end{array}$ \\
\hline $\begin{array}{l}\text { Transport, communication and } \\
\text { commercial services }\end{array}$ & $\begin{array}{l}\text { UE structural engineering } \\
\text { UE mathematics and natural sciences } \\
\text { UE economics }\end{array}$ & $\begin{array}{l}12 \\
11 \\
11\end{array}$ \\
\hline Agriculture and fisheries & $\begin{array}{l}\text { UE agriculture and environmental } \\
\text { sciences } \\
\text { UE mathematics and natural sciences } \\
\text { HVE laboratory }\end{array}$ & $\begin{array}{l}53 \\
28 \\
19\end{array}$ \\
\hline Research enterprises & $\begin{array}{l}\text { UE mathematics and natural sciences } \\
\text { UE economics } \\
\text { UE social sciences }\end{array}$ & $\begin{array}{l}42 \\
33 \\
12\end{array}$ \\
\hline Other industries & $\begin{array}{l}\text { UE civil engineering } \\
\text { UE electrical engineering }\end{array}$ & $\begin{array}{l}11 \\
10\end{array}$ \\
\hline Universities* & - & - \\
\hline Government institutions & $\begin{array}{l}\text { UE mathematics and natural sciences } \\
\text { UE social sciences }\end{array}$ & $\begin{array}{l}30 \\
11\end{array}$ \\
\hline Private non-profit organisations* & - & - \\
\hline
\end{tabular}

Source: $\mathrm{CBS} / \mathrm{ROA}$

UE = university-level education, HVE = higher vocational education; asterisk indicates that distribution is not shown, because of low cell counts.

Since mathematicians and natural scientists play such a major role in R\&D, it is interesting to get a more detailed picture of the different fields of study within this category. Therefore we turn to a survey of graduates from technical universities in the next section.

\subsection{Technical university graduates in sectors of the Dutch economy}

In table 2.2 the educational background of graduates from technical universities performing $R \& D$ in the various sectors of the Dutch economy is presented. The table 
is based on the 1988 Salary Survey (Salarisenquête) of the Royal Institute of Dutch engineers (Klvl) which reflects several aspects of employment of graduates from technical universities in 1997 (Koninklijk Instituut van Ingenieurs, 1998). This survey was performed by NSS Research and Consultancy BV, which used a different classification of economic sectors than Statistics Netherlands (CBS). Since it is impossible to get a precise match between the two classifications, we present the results in terms of the original classification. Notice that the table does not contain explicit information on the following sectors distinguished by Statistics Netherlands (CBS): the food and beverage industry, agriculture and fisheries and private nonprofit organisations. With respect to the educational background, it should be noted that the survey does not contain any information on agricultural engineers as they are not trained at technical universities (in Delft, Eindhoven, Twente) but at the agricultural university in Wageningen. The table shows only fields of study with a share of $10 \%$ or higher within a sector.

The most obvious vehicles for crowding out are engineers from types of education which undertake a considerable amount of research in different sectors of the economy. Electrical engineers have a particularly wide and significant presence in R\&D-activities in the Dutch economy: they account for more than $25 \%$ of R\&D (i.e. by technical university graduates, this qualification will be dropped in the remainder of this section) in electrical industries, transport \& telecommunication, engineering firms, software firms, and other commercial services, and more than $10 \%$ in gas, water and electricity, other government services and higher education. Technical physicists also play a pervasive role in R\&D: they are responsible for at least $10 \%$ of R\&D in metal industries, electrical industries, chemical industries, transport \& telecommunication, construction, other industries, gas, water \& electricity, other government services, higher education and the sector 'other' (which includes agriculture and fisheries).

Mechanical engineers are responsible for more than $10 \%$ of $R \& D$ in the metal industry, electro technical industry, other industries, gas, water \& electricity, engineering firms, other commercial and non-profit services and higher education. Civil engineers account for three quarters of R\&D in public works, a third of R\&D in construction and about one fifth of research in higher education. Chemical engineers are responsible for $60 \%$ of $\mathrm{R} \& \mathrm{D}$ in chemical industries, $40 \%$ in gas, water and electricity and about $28 \%$ in other industries and the sector 'other' (including agriculture and fisheries). 
Table 2.2

Fields of study of R\&D-workers educated at technical universities in the Netherlands, by economic sector, 1997

\begin{tabular}{|c|c|c|}
\hline Sector & Types of education & $\%$ share in sector \\
\hline Electrotechnical industry & $\begin{array}{l}\text { Electrical engineering } \\
\text { Mechanical engineering } \\
\text { Technical physics }\end{array}$ & $\begin{array}{l}62 \\
15 \\
14\end{array}$ \\
\hline Metal industry (narrow sense) & $\begin{array}{l}\text { Mechanical engineering } \\
\text { Technical physics }\end{array}$ & $\begin{array}{l}52 \\
14\end{array}$ \\
\hline Chemical industries & $\begin{array}{l}\text { Chemical engineering } \\
\text { Technical physics }\end{array}$ & $\begin{array}{l}60 \\
23\end{array}$ \\
\hline Transport and telecommunication & $\begin{array}{l}\text { Electrical engineering } \\
\text { Computer science } \\
\text { Technical physics }\end{array}$ & $\begin{array}{l}45 \\
24 \\
23\end{array}$ \\
\hline Engineering firms & $\begin{array}{l}\text { Electrical engineering } \\
\text { Mechanical engineering } \\
\text { Industrial design }\end{array}$ & $\begin{array}{l}29 \\
22 \\
10\end{array}$ \\
\hline Software firms & $\begin{array}{l}\text { Electrical engineering } \\
\text { Computer science } \\
\text { Technical mathematics }\end{array}$ & $\begin{array}{l}35 \\
28 \\
14\end{array}$ \\
\hline $\begin{array}{l}\text { Other commercial and non-profit } \\
\text { services }\end{array}$ & $\begin{array}{l}\text { Electrical engineering } \\
\text { Mechanical engineering }\end{array}$ & $\begin{array}{l}35 \\
32\end{array}$ \\
\hline Construction & $\begin{array}{l}\text { Structural engineering } \\
\text { Civil engineering } \\
\text { Industrial design } \\
\text { Technical physics }\end{array}$ & $\begin{array}{l}40 \\
35 \\
13 \\
12\end{array}$ \\
\hline Gas, water and electricity & $\begin{array}{l}\text { Chemical engineering } \\
\text { Technical physics } \\
\text { Electrical engineering } \\
\text { Mechanical engineering }\end{array}$ & $\begin{array}{l}40 \\
25 \\
18 \\
16\end{array}$ \\
\hline Other industries & $\begin{array}{l}\text { Chemical engineering } \\
\text { Mechanical engineering } \\
\text { Industrial design } \\
\text { Technical physics }\end{array}$ & $\begin{array}{l}28 \\
24 \\
19 \\
15\end{array}$ \\
\hline Higher education & $\begin{array}{l}\text { Civil engineering } \\
\text { Technical physics } \\
\text { Mechanical engineering } \\
\text { Electrical engineering }\end{array}$ & $\begin{array}{l}18 \\
18 \\
17 \\
13\end{array}$ \\
\hline Public works & $\begin{array}{l}\text { Civil engineering } \\
\text { Mining engineering }\end{array}$ & $\begin{array}{l}77 \\
14\end{array}$ \\
\hline Other government services & $\begin{array}{l}\text { Technical physics } \\
\text { Electrical engineering }\end{array}$ & $\begin{array}{l}30 \\
16\end{array}$ \\
\hline Other (incl. agriculture and fisheries) & $\begin{array}{l}\text { Technical physics } \\
\text { Chemical engineering } \\
\text { Mechanical engineering }\end{array}$ & $\begin{array}{l}32 \\
29 \\
10\end{array}$ \\
\hline
\end{tabular}

Source: KIvI/ROA

Share refers to R\&D performed by technical university graduates only. 


\section{Foreign R\&D-workers in the Netherlands}

An important mechanism to dampen crowding-out-effects is international labour mobility. Sectors that find it easier to substitute Dutch R\&D-workers by foreign researchers may be able to better absorb crowding-out-effects than sectors where such possibilities are less available. On the other hand, the same mechanism may also cause international crowding-out-effects, because the relative ease of substitution in the Netherlands may be mirrored in other countries. In this case, there is effectively an integrated international labour market for R\&D-workers. In order to investigate which effect dominates, an international crowding-out-model should be developed. However this is outside the scope of this study. However, by taking a look at the presence of foreign R\&D-workers in the various sectors of the Dutch economy, we can get an idea in which sectors of the Dutch economy international labour mobility plays a role.

Table 3.1

Foreign R\&D-workers in the Netherlands, by economic sector, 1997-2000

\begin{tabular}{lccc}
\hline Sector & All workers & $\begin{array}{c}\text { Workers with higher } \\
\text { education }\end{array}$ & R\&D-workers \\
& \% foreigners & \% foreigners & \% foreigners \\
& & & \\
\hline Metal industries & 12.4 & 7.8 & 11.1 \\
Chemical industries & 11.1 & 9.1 & 10.2 \\
Food and beverage industry & 13.0 & 10.6 & 9.9 \\
Transportation, communication & & 9.7 & 9.7 \\
and commercial services & 9.6 & 1.5 & $1.5^{*}$ \\
Agriculture and fisheries & 5.0 & 7.0 & 1.2 \\
Research enterprises & 6.9 & 17.8 & $17.1^{*}$ \\
Other industries & 7.1 & 7.5 & 13.8 \\
Universities & 15.6 & 1.8 & $1.8^{*}$ \\
Government institutions & 7.9 & 8.7 & 10.1 \\
Private non-profit organisations & 5.0 & & \\
All sectors & & &
\end{tabular}

Source: CBS/ROA

Asterisk indicates that percentage is based on all of workers with higher education, instead of R\&D-workers, because of low cell counts.

With respect to brain-drain-effects, the R\&D-Survey (R\&D-enquête) of Statistics Netherlands (CBS) yields no information. The Dutch Labour Force Survey (EBB), also carried out by Statistics Netherlands, does contain information on ethnicity, although the information is too rough to get a precise identification of brain-drainworkers. Therefore we will identify all non-Dutch workers ('niet-Nederlanders') and Dutch workers of foreign descent ('allochtone Nederlanders') as foreign workers. This will overstate the actual presence of foreign R\&D-workers, but if the upward bias is of equal size in all sectors, then the relative brain-drain-pattern can be informative nevertheless. After all, we are interested in the relative capacity of different sectors of the economy to absorb crowding-out-effects via international labour mobility. For $\mathrm{R} \& \mathrm{D}$-workers is seems plausible to assume that the upward bias is similar across 
sectors. Generally speaking, Dutch workers of foreign descent have a higher presence in low-skill jobs than in high-skill jobs. Affirmative action programmes for high-skill jobs are relatively new and may have less impact on R\&D-jobs than on other high-skill jobs, hence the upward bias in the public sector is probably not larger than in the private sector.

Table 3.1 was obtained from the Dutch Labour Force Survey and shows the percentage of foreign workers with R\&D-occupations in various sectors of the Dutch economy. In order to increase cell counts the average numbers for 1997, 1998, 1999, 2000 were used to calculate shares. Nevertheless, since the Dutch labour force survey aims to get an overall view of the Dutch labour force instead of people with R\&D-occupations, cell counts remained low in certain cases, in particular agriculture and fisheries, universities and private non-profit organisations.

Universities and government institutions have a relatively high percentage of foreign $R \& D$-workers, which indicates that in the public R\&D-sector crowding-out-effects may be absorbed by hiring foreign researchers. In the private sector on the other hand, there are relatively few foreign R\&D-workers in agriculture and fisheries and private non-profit organisations. As a matter of fact, none were found in the Dutch labour force survey between 1997 and 2000. This either means that these two sectors have not experienced any shortages of R\&D-workers yet, or substitution possibilities are limited. In the latter case, these sectors will not be able to use the international mobility of researchers as a way of circumventing crowding-out-effects. Notice that the percentage of foreign R\&D-workers is higher than the percentage of foreign workers of higher education. This indicates that foreign workers are more often recruited for R\&D-jobs than other high-skill-jobs. It also suggests that the percentage of foreign R\&D-workers in universities exceeds the value of 17.1 shown in table 3.1 because of low cell counts. 


\section{The crowding-out-model}

\subsection{Crowding-out-elasticities}

Crowding out of R\&D activities between sectors occurs because R\&D expenditure in one sector affects R\&D employment in other sectors through the upward effect on wages in the expanding sector. The relationship between the employment of R\&D workers in sector $i$ and R\&D expenditures in the $m(=10)$ sectors $j$ of the Dutch economy (see table 4.1) can be expressed in logarithmic form as:

\section{Equation 4.1}

Crowding-out-elasticities

$n_{i}=\theta_{i}+\sum_{j=1}^{m} \beta_{i j} x_{j}$

where $n_{i}$ is the natural logarithm of R\&D employment (measured in FTEs) in sector $i$ and $x_{j}$ is the natural logarithm of real R\&D expenditure in sector $j$. The parameters $\beta_{i j}$ can be interpreted as the 'R\&D expenditure elasticities of R\&D employment': a $1.00 \%$ increase in real R\&D expenditure in sector $\mathrm{j}$ leads to a $\beta_{\mathrm{ij}} \%$ change in the employment of R\&D workers in sector $i$. Hence the cross-elasticities $\beta_{i j}(j \neq i)$ are a direct measure of crowding out of sector $i$ by the other sectors $j(\neq i)$, while the ownelasticity $\beta_{\text {ii }}$ indicates the effect of the own R\&D expenditure on employment. Therefore we will simply call these elasticities 'crowding-out-elasticities'. They measure the effect of the various sectoral R\&D expenditures in the Dutch economy on knowledge activities in sector i (measured in FTEs).

Table 4.1

Sectors of the Dutch economy

Variable subscript Sector

\begin{aligned} \hline & Metal industries \\ 2 & Chemical industries \\ 3 & Food and beverage industry \\ 4 & Transport, communication and commercial services \\ 5 & Agriculture \& fisheries \\ 6 & Research enterprises \\ 7 & Other industries \\ 8 & Universities \\ 9 & Government institutions \\ 10 & Private non-profit organisations \\ & "Consolidated sector": aggregate of sectors that individually have no \\ & significant crowding-out-effects on the sector for which a crowding-out- \\ \hline Source: CBS/ROA & model is estimated \end{aligned}


The crowding-out-elasticities will be estimated from time series of sectoral R\&Dexpenditures and R\&D-employment from the R\&D Survey (R\&D-enquête) of Statistics Netherlands (CBS). The sector classification that will be used in the estimation is shown in table 4.1. For purposes of time series analysis there is a problem resulting from a structural break between 1993 and 1994, in particular a new definition of R\&D expenditures and employment in universities developed by Statistics Netherlands (CBS) and the Ministry of Education, Culture and Sciences (OcenW) (CBS, 1997, appendix B3). Hence data for 1994-1998 are not used in the time series analysis which will be restricted to the period 1973-1993.

Generally speaking, we expect cross-elasticities to be negative and own-elasticities to be positive. R\&D expenditure in a sector $\mathrm{j}(\neq \mathrm{i})$ will have an upward effect on wages in sector $\mathrm{j}$, attracting R\&D workers from other sectors, including sector $\mathrm{i}$. R\&D expenditure in sector $\mathrm{i}$ will increase wages in sector $\mathrm{i}$, making the sector more interesting for R\&D workers in other sectors, resulting in an increase in R\&D employment in sector i. However, in certain cases positive cross-elasticities cannot be ruled out. In particular, in universities, government institutions, private non-profit organisations specific forms of human capital can be accumulated that can yield higher wages in a later career stage by moving to a business enterprise sector. Public research institutions have a stronger emphasis on basis research, while R\&D activities in the business enterprise sector focuses more on applied research. Increases in the R\&D expenditure and wages of such a business enterprise sector, will make it worthwhile for recent science \& technology graduates to spend a couple of years in universities or other public research institutions before moving to the business enterprise sector. As a result, the R\&D expenditure in a business enterprise sector may actually increase R\&D employment in public research institutions, indicated by a positive cross-elasticity.

The size of crowding-out-elasticities is determined by demand and supply side factors. On the demand side, R\&D expenditure can be broken down into labour costs, material expenses and investment in equipment and buildings. If additional R\&D expenditures are more targeted hiring new researchers, the crowding-outeffects on other sectors will be larger. This is especially likely for sectors where R\&D is relatively labour-intensive. On the supply side, higher cross-wage elasticities of the supply of R\&D workers will lead to stronger crowding-out-effects. The size of crosswage elasticities of supply is related to the educational composition of sectoral employment and the possible substitution with foreign R\&D workers (brain-draineffects). A higher similarity of the educational composition of employment between sectors, will lead to stronger crowding-out-effects, as demand in the expanding sector may be targeted at types of education which are now working in large numbers in other sectors. A higher degree of substitutability between Dutch and foreign R\&D workers in certain occupations in certain sectors of the Dutch economy may dampen the size of crowding-out-elasticities. At the same time, a higher substitutability between Dutch and foreign R\&D-workers in the Dutch economy may be mirrored by a higher substitutability in other countries, causing outward braindrain-effects as Dutch R\&D workers are attracted by foreign research opportunities. 
Since labour market adjustments usually take some time, it is also worthwhile to make a distinction between short-term and long-term elasticities. As a matter of fact, the non-stationarity of sectoral R\&D-data implies that co-integration analysis is warranted, yielding short-term and long-term elasticities anyway. We would expect long-term crowding-out-elasticities to be larger in size than short-term crowding-outelasticities, because R\&D workers might not change sectors within one year of observed wage differences, but a prolonged premium on intersectoral mobility will have an effect on a number of R\&D workers.

\subsection{Long-term and short-term elasticities in an equilibrium correction mechanism}

Since sectoral R\&D expenditure and employment are non-stationary variables, the crowding-out-model will be formulated as an equilibrium correction mechanism (ECM). Long-term elasticities for sector $\mathrm{i}$ are estimated from the co-integrating relationship:

\section{Equation 4.2}

Long-term crowding-out-elasticities

$$
n_{i, t}=\theta_{i}+\sum_{j=1}^{m} \beta_{i j} x_{j, t}+\mu_{i, t}
$$

Short-term elasticities are estimated from equation 4.3, where the estimation results for the long-term equation are plugged into the equilibrium correction term between brackets, as suggested by the Engle \& Granger two-step estimation procedure (Engle \& Granger, 1987):

\section{Equation 4.3}

Short-term crowding-out-elasticities

$$
\Delta n_{i, t}=\sum_{j=1}^{m} \alpha_{i j} \Delta x_{j, t}+\gamma_{i}\left(n_{i, t-1}-\hat{\theta}_{i}-\sum_{j=1}^{m} \hat{\beta}_{i j} x_{j, t-1}\right)+\varepsilon_{i, t}
$$

The long-term and short-term equations can be interpreted as a sectoral crowdingout-model, which shows the short-term and long-term effects of R\&D expenditure in the own sector and in other sectors on knowledge activities (measured as FTEs) in the own sector.

\subsection{Estimation and model selection}

A first estimate of the crowding-out-model for a specific sector $i$, with $m$ regressors indicating sectoral R\&D expenditures, usually yields a number of coefficients which are insignificantly different from 0 . Traditional model selection procedures then suggest eliminating the insignificant variables from the equation and re-estimating the 
smaller model with the selected variables. However, for a crowding-out-model a different approach is warranted. Individual sectors may be too small to affect sector $\mathrm{i}$, but combined with other small sectors they may have enough clout to crowd-out sector i. Therefore; we should not eliminate insignificant variables, but consolidate the sectors that show insignificant cross-elasticities. During the model selection procedure, we will keep a consolidated sector $m+1(=11)$ in the crowding-out-model after the first iteration, as well as the own-elasticity, the constant term and the equilibrium correction term, even if these variables are insignificant. Since we use the Engle \& Granger two-step procedure, model selection will be based on the long-term equation, where we will use standard two-sided t-tests, even though the distribution of the test statistics is not standard: in fact applying the t-tests in this manner can seen as a lower bound for the true critical values. As a result, we may select variables that are not really significant. Since the variables in the short-term equation are selected according to the results of the long-term equation, we do have an indirect test of the significance of long-term elasticities. If a variable is significant in the short-term equation, then we may assume that the long-term elasticity is significant as well, given the nature of crowding out processes. In addition, a significant error correction term shows the long-term relationship plays a significant role. Anyway, an incorrect inclusion of a variable in the equation does not imply a bias in the estimates for the other elasticities. However, it does introduce inefficiency in the estimates, generating higher standard errors (Stewart, 1991, p. 65). A more direct approach is to estimate long-term and short-term parameters simultaneously instead of using the Engle \& Granger two-step method.

As mentioned earlier, we will use two-sided t-tests to select variables. Although this is a common approach, we might consider the alternative of one-sided t-tests. A model selection procedure based on two-sided t-tests can loosely be interpreted as "unrestricted estimation", as we do not care whether coefficients are positive or negative. However, economic theory suggests that own-elasticities are positive, while cross-elasticities are negative. In this case, one-sided t-tests will effectively eliminate positive cross-elasticities. Such a model selection procedure can be interpreted as "restricted estimation", or at least a practical alternative to formal estimation under inequality restrictions based on Kuhn-Tucker conditions, such as Judge \& Takayama (1966). The restrictions or one-sided t-tests do not necessarily have to be imposed on all cross-elasticities, as we have argued before that there are economic arguments why certain cross-elasticities could be positive.

Although restricted estimation yields empirical results that are by design consistent with economic theory, the unrestricted estimation results give us an idea of the empirical robustness of estimated elasticities. If the signs of elasticities found for a specific sector by unrestricted estimation are already consistent with economic theory, this gives us more confidence in the validity of the econometric model for that sector. Restricted estimation can be interpreted as a compensation for insufficient variation in the time series available. However, there is no guarantee that longer time series will yield unrestricted estimates that are consistent with economic theory. Hence restricted estimation assumes the economic theory used to impose restrictions to be true, while unrestricted estimation offers an empirical test of the 
validity of the economic theory. Policy recommendations based on such results can be made with much more confidence.

\subsection{Implied cross-elasticities}

The estimated cross-elasticity with the consolidated sector can be used to derive 'implied cross-elasticities' for the sectors that have been consolidated, based on the relative size of $R \& D$ expenditure of these sectors. Consider an equation with the own log R\&D expenditure $x_{i}, \log R \& D$ expenditure $x_{j}$ of sectors that have been selected $(j=1, \ldots, s)$ and the natural logarithm of total R\&D expenditure $x_{m+1}$ of the consolidated sector:

\section{Equation 4.4}

Model with consolidated sector

$$
n_{i}=\alpha_{i}+\beta_{i i} x_{i}+\sum_{j=1}^{s} \beta_{i j} x_{j}+\beta_{i, m+1} x_{m+1}+\varepsilon_{i}
$$

The following estimated elasticities can be distinguished.

In the first place, the own-elasticity:

$$
\frac{\partial n_{i}}{\partial x_{i}}=\beta_{i i}
$$

Secondly, the cross-elasticities of sectors $\mathrm{j}$ that have been selected:

$$
\frac{\partial n_{i}}{\partial x_{j}}=\beta_{i j}
$$

Thirdly, the cross-elasticity of the consolidated sector $m+1$ (= 11):

$$
\frac{\partial n_{i}}{\partial x_{m+1}}=\beta_{i, m+1}
$$

Now let the consolidated sector be composed of $\mathrm{p}(\leq \mathrm{m}-1)$ sectors $\mathrm{I}=1, \ldots, \mathrm{p}$. Then

$$
x_{m+1}=\log \sum_{l=1}^{p} e^{x_{l}}
$$

Hence the implied cross-elasticity of sector $\mathrm{k}$ is

$$
\frac{\partial n_{i}}{\partial x_{k}}=\beta_{i, m+1} \frac{e^{x_{k}}}{\sum_{l=1}^{p} e^{x_{l}}}=\beta_{i, m+1} \frac{X_{k}}{\sum_{l=1}^{p} X_{l}}
$$


where $X_{I}$ denotes the level (not natural logarithm) of real R\&D expenditure in sector I. Hence the implied cross-elasticity of sector $k$ is simply the product of the crosselasticity of the consolidated sector and the share of R\&D expenditure of sector $k$ in total R\&D expenditure in the consolidated sector.

Notice that similarity of educational composition of sectoral employment or substitutability with foreign R\&D workers therefore does not play a role here. As a matter of fact, the implicit assumption is that all sectors within the consolidated sector are identical in these respects vis-a-vis the sector that is crowded out. Consequently, differences in educational composition and international substitutability between the sectors that are crowding out only manifest themselves through the cross-elasticities of sectors that are not consolidated. 


\section{Estimation results}

\subsection{Metal industries}

The estimation results of the crowding-out-model for the metal industries are shown in equation 5.1 , which is an equilibrium correction mechanism explaining employment growth of R\&D workers in the metal industries $\left(\Delta \mathrm{n}_{1, t}\right)$ as a function of the growth of $R \& D$ expenditure in the metal industries $\left(\Delta x_{1, t}\right)$, the growth of $R \& D$ expenditure in the consolidated sector $\left(\Delta \mathrm{x}_{11, \mathrm{t}}\right)$ and the equilibrium correction term between brackets. Standard errors are given in brackets directly below the estimated coefficients, significance at the $5 \%$ level is indicated by an asterisk. The values of the $R^{2}$, DurbinWatson (DW) statistic and the Breusch-Godfrey Lagrange Multiplier (LM) test for first order serial correlation are also shown. Significance at the $5 \%$ level of the LM-test is also indicated by an asterisk. The explained part of the estimated long-term equation is also shown $\left(\lambda_{1, t}\right)$ and is used in the equilibrium correction term, according to the Engle \& Granger two-step estimation method. The estimation results indicate that the metal industries suffer from crowding out mostly in the long run: the short-run crosselasticities do not differ significantly from zero. There is no specific sector responsible for crowding out, as indicated by the absence of cross-elasticities for specific sectors.

$$
\begin{aligned}
& \text { Equation } 5.1 \\
& \text { Crowding-out-model for the metal industries } \\
& \Delta n_{1, t}=0.50 \Delta x_{1, t}-0.26 \Delta x_{11, t}-1.21\left(n_{1, t-1}-\lambda_{1, t-1}\right)+\varepsilon_{1, t} \\
& (0.11)^{*} \quad(0.25) \quad(0.24)^{*} \\
& \mathrm{R}^{2}=0.71 \quad \mathrm{DW}=2.03 \quad \mathrm{LM}=0.51 \\
& \lambda_{1, t}=5.75+0.48 x_{1, t}-0.29 x_{11, t} \\
& (1.22)^{*}(0.06)^{*} \quad(0.09)^{*} \\
& R^{2}=0.80 \quad D W=2.15 \quad L M=1.53
\end{aligned}
$$

Sample period: 1973-1993

The contribution to the crowding out of the metal industries by each sector is shown in table 5.1, which shows both the estimated and the implied elasticities by sector. Estimates which are significantly different from 0 are indicated by an asterisk, as are implied elasticities derived from a significant cross-elasticity of the consolidated sector. As mentioned earlier, the contributions of consolidated sectors are based on the relative size of each sector. Especially in the long run, there are noticeable crowding-out-effects from the chemical industries, universities and government institutions. Physicists, electrical engineers and mechanical engineers are most likely to be involved in the crowding-out-processes for metal industries, as can be inferred 
from table 2.1 and 2.2. The presence of foreign R\&D-workers does not seem to have a particularly accelerating or decelerating effect on crowding out, since their presence in metal industries is about average, as can be seen from table 3.1.

Table 5.1

Crowding out of the metal industries: estimated and implied elasticities, 1973-1993

\begin{tabular}{|c|c|c|}
\hline Sector & Short-term elasticity & Long-term elasticity \\
\hline $\begin{array}{l}\text { Metal industries } \\
\text { Chemical industries } \\
\text { Food and beverage industry } \\
\text { Transport, communication and commercial } \\
\text { services } \\
\text { Agriculture and fisheries } \\
\text { Research enterprises } \\
\text { Other industries } \\
\text { Universities } \\
\text { Government institutions } \\
\text { Private non-profit organisations }\end{array}$ & $\begin{array}{l}0.50^{*} \\
-0.06 \\
-0.01 \\
-0.01 \\
-0.00 \\
-0.00 \\
-0.01 \\
-0.09 \\
-0.07 \\
-0.01\end{array}$ & $\begin{array}{l}0.48^{*} \\
-0.07^{*} \\
-0.02^{*} \\
-0.01^{*} \\
-0.01^{*} \\
-0.00^{*} \\
-0.01^{*} \\
-0.10^{*} \\
-0.07^{*} \\
-0.01^{*}\end{array}$ \\
\hline
\end{tabular}

\subsection{Chemical industries}

Employment of R\&D workers in the chemical industries is crowded out most prominently by R\&D expenditure in agriculture and fisheries. In the long run, there are also crowding-out-effects from the metal industries, universities and government institutions, as implied by the significant long-run elasticity of the consolidated sector. Crowding out by agriculture and fisheries is most likely to involve natural scientists and laboratory technicians, as suggested by table 2.1. Notice that these two types of education account for almost half of the stock of R\&D-workers in both sectors. Physicists and chemists will be the candidates to flow out to the metal industries, universities and government institutions. The presence of foreign R\&D-workers in the chemical industries does not differ from the average for the whole economy (table 3.1) and at its present level does not fully compensate the aforementioned crowding-out-effects.

Table 5.2

Crowding out of the chemical industries: estimated and implied elasticities, 1973-1993

\begin{tabular}{|c|c|c|}
\hline Sector & Short-term elasticity & Long-term elasticity \\
\hline $\begin{array}{l}\text { Metal industries } \\
\text { Chemical industries } \\
\text { Food and beverage industry } \\
\text { Transport, communication and } \\
\text { services } \\
\text { Agriculture and fisheries } \\
\text { Research enterprises } \\
\text { Other industries } \\
\text { Universities } \\
\text { Government institutions } \\
\text { Private non-profit organisations }\end{array}$ & $\begin{array}{l}-0.03 \\
0.65^{\star} \\
-0.01 \\
-0.00 \\
-0.24^{\star} \\
-0.00 \\
-0.00 \\
-0.03 \\
-0.03 \\
-0.00\end{array}$ & $\begin{array}{l}-0.07^{*} \\
0.68^{*} \\
-0.01^{*} \\
-0.01^{*} \\
-0.21^{*} \\
-0.00^{*} \\
-0.01^{*} \\
-0.07^{*} \\
-0.06^{*} \\
-0.01^{*}\end{array}$ \\
\hline
\end{tabular}




\section{Equation 5.2}

Crowding-out-model for the chemical industries

$$
\begin{aligned}
& \Delta n_{2, t}= 0.65 \Delta x_{2, t}-0.24 \Delta x_{5, t}-0.11 \Delta x_{11, t}-1.54\left(n_{2, t-1}-\lambda_{2, t-1}\right)+\varepsilon_{2, t} \\
& \begin{array}{ll}
(0.08)^{*} \quad(0.04)^{*} \quad(0.09) & (0.28)^{*}
\end{array} \\
& \mathrm{R}^{2}= 0.87 \mathrm{DW}=1.88 \mathrm{LM}=0.18 \\
& \lambda_{2, t}= 3.87+0.68 x_{2, t}-0.21 x_{5, t}-0.23 x_{11, t} \\
&(1.07)^{*} \quad(0.08)^{*} \quad(0.04)^{*} \quad(0.09)^{*} \\
& \mathrm{R}^{2}= 0.87 \mathrm{DW}=2.41 \quad \mathrm{LM}=3.18
\end{aligned}
$$

Sample period: $1973-1993$

\subsection{Food and beverage industry}

The food and beverage industry is crowded out by the metal industries and universities. The considerable implied cross-elasticities of the chemical industries and government institutions are not significantly different from zero. Crowding out by metal industries will probably involve mathematicians, natural scientists and mechanical engineers. In addition, economists, MBAs and industrial engineers may be attracted by universities. International labour mobility is comparable to the national average and at its current rate does not absorb the crowding-out-effects.

\section{Equation 5.3:}

Crowding-out-model for the food and beverage industry

$$
\begin{aligned}
& \Delta n_{3, t}=-0.22 \Delta x_{1, t}+1.11 \Delta x_{3, t}-0.24 \Delta x_{8, t}-0.34 \Delta x_{11, t}-0.81\left(n_{3, t-1}-\lambda_{3, t-1}\right)+\varepsilon_{3, t} \\
& \begin{array}{llll}
(0.08)^{*} \quad(0.05)^{*} \quad(0.11)^{*} \quad(0.20) \quad(0.22)^{*}
\end{array} \\
& R^{2}=0.97 \quad \mathrm{DW}=1.73 \quad \mathrm{LM}=1.11 \\
& \lambda_{3, t}=7.84-0.12 x_{1, t}+1.11 x_{3, t}-0.51 x_{8, t}-0.37 x_{11, t} \\
& \begin{array}{llll}
(0.90)^{*}(0.05)^{*} \quad(0.07)^{*} \quad(0.16)^{*} \quad(0.20)
\end{array} \\
& R^{2}=0.95 \quad \mathrm{DW}=1.56 \quad \mathrm{LM}=1.19
\end{aligned}
$$

Sample period: 1973-1993 
Table 5.3

Crowding out of the food and beverage industry: estimated and implied elasticities, 1973-1993

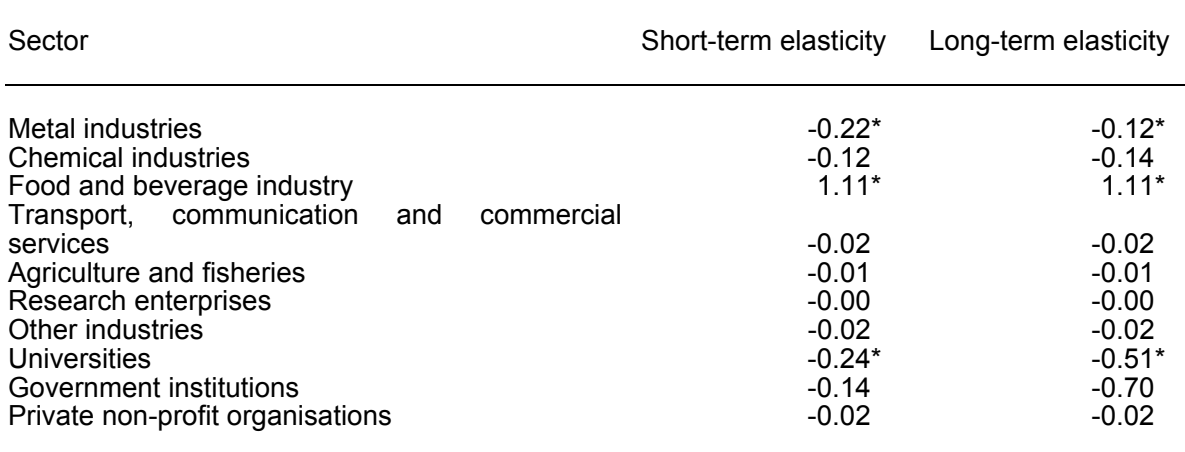

\subsection{Transport, communication and commercial services}

The transport, communication and commercial services sector is not affected by any statistically significant crowding out in the short run, but in the long run metal industries, chemical industries, universities and government institutions have large and significant implied cross-elasticities. Electrical engineers, computer scientists and physicists are likely to play a role in these crowding-out-processes. Economists may also be involved in crowding out by the public sector. The role of foreign R\&Dworkers does not differ from the average of the Dutch economy and therefore does not alleviate the crowding-out-effects more than elsewhere.

$$
\begin{aligned}
& \text { Equation 5.4: Crowding-out-model for transport, communication and services } \\
& \begin{aligned}
\Delta n_{4, t}= & 1.02 \Delta x_{4, t}-0.49 \Delta x_{11, t}-0.64\left(n_{4, t-1}-\lambda_{4, t-1}\right)+\varepsilon_{4, t} \\
(0.17)^{*} & (0.24) \quad(0.26)^{*}
\end{aligned} \\
& R^{2}=0.66 \quad \mathrm{DW}=1.51 \quad \mathrm{LM}=0.86 \\
& \lambda_{4, t}=0.27+1.09 x_{4, t}-0.60 x_{11, t} \\
& \begin{array}{lll}
(1.68) & (0.13)^{*} \quad(0.16)^{*} \\
\mathrm{R}^{2}= & 0.90 \quad \mathrm{DW}=1.13 \quad \mathrm{LM}=2.86
\end{array}
\end{aligned}
$$

Sample period: $1973-1993$ 
Table 5.4

Crowding out of transport, communication and commercial services: estimated and implied elasticities, 1973-1993

\begin{tabular}{lcr}
\hline Sector & Short-term elasticity & $\begin{array}{r}\text { Long-term } \\
\text { elasticity }\end{array}$ \\
\hline Metal industries & -0.12 & $-0.15^{*}$ \\
Chemical industries & -0.09 & $-0.11^{*}$ \\
Food and beverage industry & -0.02 & $-0.03^{*}$ \\
Transport, communication and commercial services & $1.02^{*}$ & $1.09^{*}$ \\
Agriculture and fisheries & -0.01 & $-0.01^{*}$ \\
Research enterprises & -0.00 & $-0.00^{*}$ \\
Other industries & -0.02 & $-0.02^{*}$ \\
Universities & -0.13 & $-0.15^{*}$ \\
Government institutions & -0.10 & $-0.12^{*}$ \\
Private non-profit organisations & -0.01 & $-0.02^{*}$ \\
\hline
\end{tabular}

\subsection{Agriculture and fisheries}

The crowding-out-model for agriculture and fisheries shown in equation 5.5 and table 5.5 does not make much sense, as the consolidated sector has a positive coefficient which is significantly different from zero. In theory, a positive cross-elasticity could be explained from a dynamic perspective. Recent graduates could have an incentive to accumulate human capital in a sector in order to obtain higher wages in another sector later in their careers. This argument may hold for universities and government institutions, because public sector R\&D is often more focused on basic research instead of applied research. However, it seems less likely for other sectors. Therefore in equation 5.5a we also present a crowding-out-model for agriculture and fisheries which does not include a consolidated sector.

\section{Equation 5.5}

Crowding-out-model for agriculture and fisheries

$$
\begin{aligned}
& \Delta n_{5, t}=-0.25 \Delta x_{1, t}+0.58 \Delta x_{5, t}+0.73 \Delta x_{11, t}-0.86\left(n_{5, t-1}-\lambda_{5, t-1}\right)+\varepsilon_{5, t}
\end{aligned}
$$

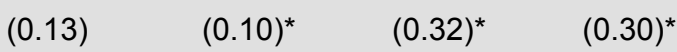

$$
\begin{aligned}
& \mathrm{R}^{2}=0.75 \quad \mathrm{DW}=1.91 \quad \mathrm{LM}=0.32 \\
& \lambda_{5, t}=-18.13-0.23 x_{1, t}+0.49 x_{5, t}+0.91 x_{11, t} \\
& (3.17)^{*}(0.07)^{*} \quad(0.10)^{*} \quad(0.22)^{*} \\
& \mathrm{R}^{2}=0.98 \quad \mathrm{DW}=1.66 \quad \mathrm{LM}=0.49
\end{aligned}
$$

Sample period: $1973-1993$ 
Table 5.5

Crowding out of agriculture and fisheries: estimated and implied elasticities, 1973-1993

Sector

Short-term elasticity Long-term elasticity

Metal industries

Chemical industries

Food and beverage industry

Transport, communication and commercial services

Agriculture and fisheries

Research enterprises

Other industries

Universities

Government institutions

Private non-profit organisations

The estimation procedure without the formation of a consolidated sector yields more plausible results, as is shown in equation 5.5a. Again no significant cross-elasticities are found, while now we have excluded the consolidated sector by design. Notice that the short-term equation considerably reduces the serial correlation exhibited by the long-term equation. The absence of crowding-out-mechanisms both in equation 5.5 and $5.5 \mathrm{a}$ is definitely not explained by brain-drain-effects. As a matter of fact, this sector has the lowest percentage of foreign knowledge workers in the Dutch economy. A possible candidate for crowding out suggested by the educational composition of the agriculture and fisheries sector (table 2.1) is the chemical industry. However, the estimation results in equation 5.5 and $5.5 \mathrm{a}$ indicate that the agriculture and fisheries sector crowds out the chemical industries and not the other way round.

\section{Equation $5.5 a$}

Crowding-out-model for agriculture and fisheries without consolidated sector

$$
\begin{aligned}
& \Delta n_{5, t}=0.73 \Delta x_{5, t}-0.24\left(n_{5, t-1}-\lambda_{5, t-1}\right)+\varepsilon_{5, t} \\
& (0.10)^{*} \quad(0.19) \\
& R^{2}=0.62 \quad D W=1.95 \quad L M=0.25 \\
& \lambda_{5, t}=-7.74+0.78 x_{5, t} \\
& (0.70)^{*}(0.04)^{*} \\
& R^{2}=0.96 \quad \mathrm{DW}=0.59 \quad \mathrm{LM}=10.20^{*}
\end{aligned}
$$

Sample period: $1973-1993$ 


\subsection{Research enterprises}

Research enterprises are free of crowding-out-effects, with the exception of private non-profit organisations. Mathematicians, natural scientists, economists and social scientists may play a role in these effects. The inflow of foreign R\&D-workers, which is about average compared with other sectors, does not completely offset the crowding-out-effect by private non-profit organisations.

\section{Equation 5.6}

Crowding-out-model for research enterprises

$$
\begin{aligned}
& \Delta n_{6, t}=0.68 \Delta x_{6, t}-0.48 \Delta x_{10, t}+0.06 \Delta x_{11, t}-0.84\left(n_{6, t-1}-\lambda_{6, t-1}\right)+\varepsilon_{6, t} \\
& \begin{array}{llll}
(0.06)^{*} \quad(0.09)^{*} \quad(0.14) \quad(0.25)^{*} &
\end{array} \\
& \mathrm{R}^{2}=0.90 \quad \mathrm{DW}=1.85 \quad \mathrm{LM}=2.83 \\
& \lambda_{6, t}=1.95+0.67 x_{6, t}-0.48 x_{10, t}+0.05 x_{11, t} \\
& \begin{array}{lll}
(1.18) & (0.05)^{*} \quad(0.06)^{*} \quad(0.06)
\end{array} \\
& \mathrm{R}^{2}=0.97 \quad \mathrm{DW}=1.65 \quad \mathrm{LM}=0.57
\end{aligned}
$$

Sample period: $1973-1993$

Table 5.6

Crowding out of research enterprises: estimated and implied elasticities, 1973-1993

\begin{tabular}{lcr}
\hline Sector & Short-term elasticity & Long-term elasticity \\
& & \\
\hline & & 0.01 \\
Metal industries & 0.02 & 0.01 \\
Chemical industries & 0.01 & 0.00 \\
Food and beverage industry & 0.00 & 0.00 \\
Transport, communication and commercial services & 0.00 & 0.00 \\
Agriculture and fisheries & 0.00 & $0.67^{*}$ \\
Research enterprises & $0.68^{*}$ & 0.00 \\
Other industries & 0.00 & 0.01 \\
Universities & 0.02 & 0.01 \\
Government institutions & 0.01 & $-0.48^{*}$ \\
Private non-profit organisations & $-0.48^{*}$ &
\end{tabular}

\subsection{Other industries}

In the crowding-out-model for other industries, the coefficient for the consolidated sector is neither significant in the short-term equation nor in the long-term equation. Hence the employment of R\&D workers in other industries does not seem to be affected by crowding-out-phenomena caused by R\&D expenditure in other sectors. 
The presence of foreign R\&D-workers is comparable with the national average, hence we should be careful in attributing the lack of crowding-out-effects to international labour mobility. An alternative explanation is that this sector is rather heterogeneous, which may explain why crowding-out-effects are difficult to detect. This might require a lower level of aggregation.

Equation 5.7:

Crowding-out-model for other industries

$$
\begin{aligned}
\Delta n_{7, t}= & 0.52 \Delta x_{7, t}-0.02 \Delta x_{11, t}-0.70\left(n_{7, t-1}-\lambda_{7, t-1}\right)+\varepsilon_{7, t} \\
R^{2}= & 0.73 \quad \mathrm{DW}=1.53 \quad \mathrm{LM}=1.53 \\
\lambda_{7, t}= & -8.44+0.56 x_{7, t}+0.22 x_{11, t} \\
& \begin{array}{ll}
(1.69)^{*} \quad(0.09)^{*} \quad(0.12) \\
\mathrm{R}^{2}= & 0.93 \quad \mathrm{DW}=1.23 \quad \mathrm{LM}=2.39
\end{array}
\end{aligned}
$$

Sample period: $1973-1993$

Table 5.7

Crowding out of other industries: estimated and implied elasticities, 1973-1993

\begin{tabular}{lcc} 
Sector & Short-term elasticity & Long-term elasticity \\
& & \\
\hline Metal industries & & 0.05 \\
Chemical industries & -0.00 & 0.04 \\
Food and beverage industry & -0.00 & 0.01 \\
Transport, communication and commercial services & -0.00 & 0.01 \\
Agriculture and fisheries & -0.00 & 0.00 \\
Research enterprises & -0.00 & 0.00 \\
Other industries & -0.00 & $0.56^{*}$ \\
Universities & $0.52^{*}$ & 0.06 \\
Government institutions & -0.00 & 0.04 \\
Private non-profit organisations & -0.00 & 0.01
\end{tabular}

\subsection{Universities}

Universities do not seem to suffer from crowding out either. The coefficients for the consolidated sector are insignificantly different from zero, both in the short and the long run. The above average presence of foreign knowledge workers in universities, as discussed in chapter 3, may offer an explanation of this result. The stronger emphasis on basic research in academia as opposed to applied research in the private sector may also play a role. However, it is not the existence of compensating wage differentials itself which can explain this result. Crowding out is dampened only 
if the actual wage difference between the public and the private sector is considerably smaller than the compensating wage differential. As soon as the actual wage difference surpasses the compensating wage differental, there will in fact be a large outflow of R\&D-workers from the public sector.

\section{Equation 5.8}

Crowding-out-model for universities

$$
\begin{aligned}
& \Delta n_{8, t}=1.14 \Delta x_{8, t}+0.01 \Delta x_{11, t}-0.92\left(n_{8, t-1}-\lambda_{8, t-1}\right)+\varepsilon_{8, t} \\
& (0.24)^{*} \quad(0.26) \quad(0.20)^{*} \\
& R^{2}=0.71 \quad D W=2.13 \quad L M=0.31 \\
& \lambda_{8, t}=-10.84+0.81 x_{8, t}+0.14 x_{11, t} \\
& (1.99)^{*} \quad(0.22)^{*} \quad(0.20) \\
& R^{2}=0.85 \quad D W=1.46 \quad L M=2.89
\end{aligned}
$$

Sample period: 1973-1993

Universities are a possible candidate for positive cross-elasticities, as recent graduates who have to make a choice between a research position at a university or in the private sector, may be tempted to start their professional career in academia, in order to capitalize on their accumulated human capital later in their careers by moving to the private sector. The estimated cross-elasticity for the consolidated sector is positive both in the short and the long run, however not significantly so.

Table 5.8

Crowding out of universities: estimated and implied elasticities, 1973-1993

\begin{tabular}{lcc}
\hline Sector & Short-term elasticity & Long-term elasticity \\
& & \\
\hline Chemical industries & & 0.03 \\
Food and beverage industry & 0.00 & 0.01 \\
Transport, communication and commercial services & 0.00 & 0.01 \\
Agriculture and fisheries & 0.00 & 0.00 \\
Research enterprises & 0.00 & 0.00 \\
Other industries & 0.00 & 0.01 \\
Universities & 0.00 & $0.81^{*}$ \\
Government institutions & $1.14^{*}$ & 0.04 \\
Private non-profit organisations & 0.00 & 0.01
\end{tabular}

\subsection{Government institutions}

The government sector is another likely candidate for positive cross-elasticities, as specific human capital can be accumulated in government institutions and be 
rewarded in a later career stage by moving to the private sector. Equation 5.9 shows that the positive long-run cross-elasticity for the consolidated sector is significant, while the short-term elasticity is not. The same argument may explain why the ownelasticity is not significantly different from zero. In equation 5.9a we present a crowding-out-model without a consolidated sector which appears to make more sense. The absence of negative cross-elasticities may be explained from the above average presence of foreign R\&D-workers in government institutions and individual preferences for public sector R\&D, which is more focused on basic research.

\section{Equation 5.9}

Crowding-out-model for government institutions

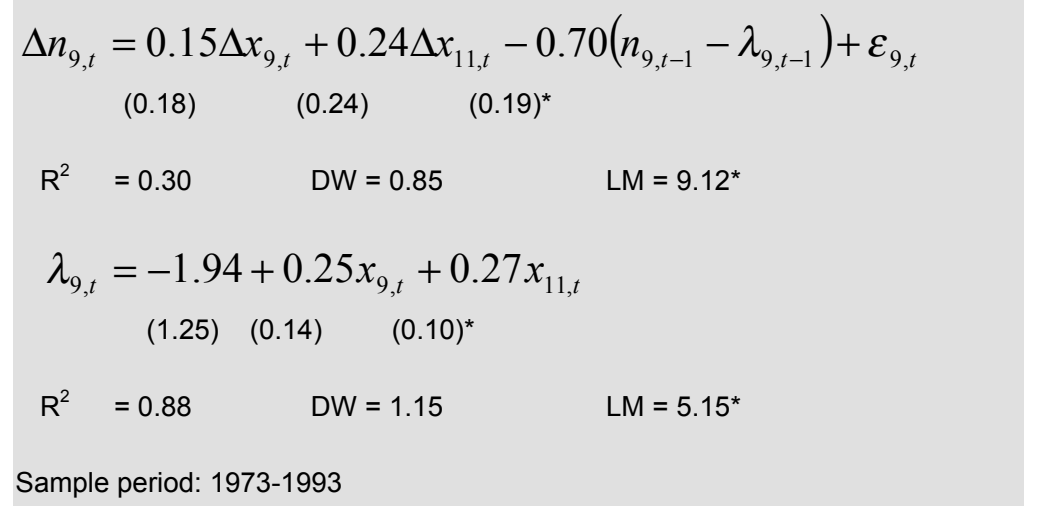

Table 5.9

Crowding out of government institutions: estimated and implied elasticities, 1973-1993

Sector Short-term elasticity Long-term elasticity

Metal industries

Chemical industries

Food and beverage industry

Transport, communication and commercial services

Agriculture and fisheries

Research enterprises

Other industries

Universities

Government institutions

Private non-profit organisations

$\begin{array}{ll}0.07 & 0.08^{*} \\ 0.05 & 0.06^{*} \\ 0.01 & 0.01^{*} \\ 0.01 & 0.01^{*} \\ 0.00 & 0.00^{*} \\ 0.00 & 0.00^{*} \\ 0.01 & 0.01^{*} \\ 0.07 & 0.08^{*} \\ 0.15 & 0.25^{*} \\ 0.01 & 0.01^{*}\end{array}$

Equation 5.9a supports the evidence provided by equation 5.9 that there are no significant crowding-out-effects from other sectors. The positive cross-elasticity for the consolidated sector (significant in the long run) is eliminated by design in this equation. This considerably improves the relative precision of the estimate for the own-elasticity, yielding a statistically significant coefficient, both in the short and the long run. The $\mathrm{R}^{2}$ for the short-term relationship in equation $5.9 \mathrm{a}$ is however alarmingly low. Serial correlation remains a problem, as was the case in equation 5.9. Although we conclude that government institutions do not suffer from crowding out by other sectors, it remains unclear whether there is a positive cross-elasticity 
with the consolidated sector. A more detailed lag structure of responses of R\&D employment to R\&D expenditure seems to be at work in the government sector.

\section{Equation 5.9a:}

Crowding-out-model for government institutions without consolidated sector

$$
\begin{aligned}
\Delta n_{9, t}= & 0.38 \Delta x_{9, t}-0.51\left(n_{9, t-1}-\lambda_{9, t-1}\right)+\varepsilon_{9, t} \\
& (0.17)^{*} \quad(0.20)^{*} \\
\mathrm{R}^{2}= & 0.04 \quad \mathrm{DW}=0.79 \quad \mathrm{LM}=8.15^{*} \\
\lambda_{9, t}= & -3.33+0.60 x_{9, t} \\
\mathrm{R}^{2}= & 0.83 \quad \mathrm{DW}=0.99 \quad \mathrm{LM}=6.72^{*}
\end{aligned}
$$

Sample period: $1973-1993$

\subsection{Private non-profit organisations}

The crowding-out-model for private non-profit organisations suggests that this sector is virtually unaffected by R\&D expenditure in other sectors, as the cross-elasticity for the consolidated sector is statistically insignificant. Brain-drain-effects are certainly not an explanation for this result, since private non-profit organisations are in fact least likely to employ foreign R\&D-workers.

Table 5.10

Crowding out of private non-profit organisations: estimated and implied elasticities, 1973-1993

Sector Short-term elasticity Long-term elasticity

Metal industries

Chemical industries

Food and beverage industry

Transport, communication and commercial services

Agriculture and fisheries

Research enterprises

Other industries

Universities

Government institutions

Private non-profit organisations
Short-term elasticity Long-term elasticity

$\begin{array}{ll}0.00 & 0.02 \\ 0.00 & 0.02 \\ 0.00 & 0.00 \\ 0.00 & 0.00 \\ 0.00 & 0.00 \\ 0.00 & 0.00 \\ 0.00 & 0.00 \\ 0.00 & 0.02 \\ 0.00 & 0.02 \\ 0.35^{\star} & 0.44^{\star}\end{array}$




$$
\begin{aligned}
& \text { Equation } 5.10 \\
& \text { Crowding-out-model for private non-profit organisations } \\
& \begin{aligned}
\begin{aligned}
\Delta n_{10, t}= & 0.35 \Delta x_{10, t}+0.01 \Delta x_{11, t}-0.47\left(n_{10, t-1}-\lambda_{10, t-1}\right)+\varepsilon_{10, t} \\
(0.08)^{*} \quad(0.11) & (0.20)^{*}
\end{aligned} \\
R^{2}=0.54 \quad \mathrm{DW}=1.63 \quad \mathrm{LM}=0.63 \\
\lambda_{10, t}=-3.25+0.44 x_{10, t}+0.09 x_{11, t} \\
(0.69)^{*}(0.06)^{*} \quad(0.07) \\
R^{2}=0.95 \quad \mathrm{DW}=1.00 \quad \mathrm{LM}=5.08^{*}
\end{aligned}
\end{aligned}
$$

Sample period: 1973-1993 


\section{Crowding-out-effects of sectoral R\&D-expenditures}

In chapter 5 the crowding-out-mechanisms in the Dutch labour market for R\&Dworkers were discussed from the perspective of the sectors that are crowded out. This meant that in each section of chapter 5 we looked at a different sector and analysed by which other sectors it was crowded out. However, for policy purposes it may be more interesting to take the perspective of sectors that are crowding out. More specifically, suppose R\&D expenditure in a certain sector is increased, what are the crowding-out-effects for other sectors? As a baseline scenario we first show the long-term effects on R\&D employment if there is a sustained economy-wide increase in $R \& D$ expenditure of $1.0 \%$. Table 6.1 is computed according to:

\section{Equation 6.1}

Effect of economy-wide increase in R\&D-expenditures by $1.0 \%$

$$
\% \Delta n_{i}^{(0)}=\beta_{i i}+\sum_{\substack{j=1 \\ j \neq i}}^{m} \beta_{i j}
$$

The estimated and implied elasticities in equation 6.1 are given in tables 5.1-5.10. For agriculture and fisheries and government institutions we used the models without a consolidated sector, i.e. equation $5.5 a$ and equation 5.9 a.

Table 6.1

Effect of economy-wide increase in R\&D expenditure of $1.0 \%$ (baseline scenario)

Sector \% increase in R\&D-employment

$\begin{array}{ll}\text { Metal industries } & 0.19 \\ \text { Chemical industries } & 0.24 \\ \text { Food and beverage industry } & 0.11 \\ \text { Transport, communication and commercial services } & 0.49 \\ \text { Agriculture and fisheries } & 0.78 \\ \text { Research enterprises } & 0.24 \\ \text { Other industries } & 0.78 \\ \text { Universities } & 0.95 \\ \text { Government institutions } & 0.60 \\ \text { Private non-profit organisations } & 0.53\end{array}$

The size of the effects in table 6.1 reflect the net result of the own-elasticity and the crowding-out-elasticities. Sectors that are not crowded out show larger effects: agriculture and fisheries, other industries, universities, government institutions and private non-profit organisations. The other sectors benefit less from an economywide increase in R\&D expenditure. From a policy perspective, table 6.1 yields information on the effects of sector-neutral innovation policies. The results indicate that a sector-neutral policy leads to stronger increases in R\&D-workers in sectors that are not crowded out, than in sectors that suffer from crowding out. 
In reality, the growth rates of $R \& D$ expenditures may differ between sectors of the economy. Certain sectors may rationally choose to intensify their R\&D-efforts, either financed internally, in the capital markets or by public means. The last case may lead to a sector bias in innovation policy expenditures (see for example table 1.2), even when this is not intended by the policy measure.

We show the effects of biased growth of R\&D expenditures in the following tables. Table 6.1 serves as the baseline scenario of sector-neutral growth. In table 6.2 the long-term effect of a sustained $2.0 \%$ increase in R\&D expenditure in the metal industries is shown, if R\&D expenditures in all other sectors grow the baseline rate of $1.0 \%$. The net effect on R\&D employment in other sectors can be calculated according to:

Equation 6.2:

Effect of biased growth in R\&D expenditures

$$
\% \Delta n_{i}^{(k)}=\beta_{i i}+\sum_{\substack{j=1 \\ j \neq i \\ j \neq k}}^{m} \beta_{i j}+2 \beta_{i k}
$$

Hence the additional effect of an extra percent growth in R\&D expenditure in the metal industries can be computed as:

Equation 6.3:

Crowding-out-effect of biased growth in $R \& D$ expenditures

$$
\% \Delta n_{i}^{(k)}-\% \Delta n_{i}^{(0)}=\beta_{i k}
$$

The effects shown in table 6.2 show that the growth of R\&D employment in the chemical industries is reduced from $0.24 \%$ in the baseline scenario to $0.17 \%$ in case of a sector-bias in favour of metal industries. The transport, communication and commercial services sector is also negatively affected (from $0.49 \%$ to $0.34 \%$ ), while R\&D employment in the food and beverage industry actually shrinks as a result from crowding out by the metal industries.

Table 6.2

Crowding out by the metal industries

\begin{tabular}{lrr}
\hline Sector & $\begin{array}{r}\text { \% increase in } \\
\text { R\&D-employment } \\
\text { (additional effect) }\end{array}$ & $\begin{array}{r}\text { \% increase in } \\
\text { R\&D-employment } \\
\text { (net effect) }\end{array}$ \\
\hline Metal industries & 0.48 & 0.67 \\
Chemical industries & -0.07 & 0.17 \\
Food and beverage industry & -0.12 & -0.01 \\
Transport, communication and commercial services & -0.15 & 0.34
\end{tabular}


In table 6.3 a similar scenario is shown where R\&D expenditure in the chemical industries grows faster than the other sectors. The rise in R\&D employment in the metal industries falls from $0.19 \%$ to $0.12 \%$. In the transport, communication and commercial services sector the growth of R\&D employment is reduced from $0.49 \%$ to $0.38 \%$. Again the food and beverage industry exhibits negative growth due to crowding out.

Table 6.3

Crowding out by the chemical industries

\begin{tabular}{lrr}
\hline Sector & $\begin{array}{r}\text { \% increase in } \\
\text { R\&D-employment } \\
\text { (additional effect) }\end{array}$ & $\begin{array}{r}\text { \% increase in } \\
\text { R\&D-employment } \\
\text { (net effect) }\end{array}$ \\
\hline Metal industries & -0.07 & 0.12 \\
Chemical industries & 0.68 & 0.92 \\
Food and beverage industry & -0.14 & -0.03 \\
Transport, communication and commercial services & -0.11 & 0.38 \\
\hline
\end{tabular}

In table 6.4 the third significant crowding-out-mechanism is shown: crowding out by the agriculture and fisheries sector. The growth of R\&D employment in the chemical industries is reduced from $0.24 \%$ to $0.03 \%$. Hence a bias of this size in favour of agriculture and fisheries almost nullifies employment growth in the chemical industries. This scenario is particularly relevant in light of table 1.2 which shows that Dutch innovation policy exhibits a bias in favour of agriculture and fisheries and against chemical industries. However, we cannot draw solid conclusions on the exact effects of Dutch innovation policy expenditures in 1999, since the econometric analysis is restricted to $1973-1993$.

Table 6.4

Crowding out by agriculture and fisheries

\begin{tabular}{lcc}
\hline Sector & $\begin{array}{r}\text { \% increase in } \\
\text { R\&D-employment } \\
\text { (additional effect) }\end{array}$ & $\begin{array}{r}\text { \% increase in } \\
\text { R\&D-employment } \\
\text { (net effect) }\end{array}$ \\
\hline Chemical industries & -0.21 & 0.03 \\
\hline
\end{tabular}

In table 6.5 and 6.6 the effect of crowding out of by the public sector is shown. An accelerated growth in R\&D expenditure by universities (table 6.5) has a strong negative impact on R\&D employment in the food and beverage industry, where a modest positive growth of $0.11 \%$ is turned around into a considerable shrinkage of $0.40 \%$. R\&D employment growth in the metal industries is cut in half, while the chemical industries and the transport, communication and commercial services sector lose about a third of employment growth. 
Table 6.5

Crowding out by universities

\begin{tabular}{lrr}
\hline Sector & $\begin{array}{r}\text { \% increase in R\&D } \\
\text { employment } \\
\text { (additional effect) }\end{array}$ & $\begin{array}{r}\text { \% increase in } \\
\text { R\&D-employment } \\
\text { (net effect) }\end{array}$ \\
\hline Metal industries & -0.10 & 0.09 \\
Chemical industries & -0.07 & 0.17 \\
Food and beverage industry & -0.51 & -0.40 \\
Transport, communication and commercial services & -0.15 & 0.34 \\
Universities & 0.81 & 1.76
\end{tabular}

An accelerated growth of R\&D expenditure in government institutions (table 6.6) has a similar effect. R\&D employment in the food and beverage industry falls by $0.59 \%$, while the metal industries, chemical industries and transport, communication and commercial services lose between a quarter and a third of R\&D employment growth.

Table 6.6

Crowding out by government institutions

\begin{tabular}{lrr}
\hline Sector & $\begin{array}{r}\text { \% increase in } \\
\text { R\&D-employment } \\
\text { (additional effect) }\end{array}$ & $\begin{array}{r}\text { \% increase in } \\
\text { R\&D-employment } \\
\text { (net effect) }\end{array}$ \\
\hline Metal industries & -0.07 & 0.12 \\
Chemical industries & -0.06 & 0.18 \\
Food and beverage industry & -0.70 & -0.59 \\
Transport, communication and commercial services & -0.12 & 0.37 \\
Government institutions & $0.60^{*}$ & $1.20^{*}$ \\
\hline
\end{tabular}

The last crowding-out-mechanism is described in table 6.7. A disproportionate growth in R\&D expenditure by private non-profit organisations turns around a $0.24 \%$ increase in R\&D employment in research enterprises into a decrease of the same magnitude.

Table 6.7

Crowding out by private non-profit organisations

\begin{tabular}{lrr}
\hline Sector & $\begin{array}{r}\text { \% increase in } \\
\text { R\&D-employment } \\
\text { (additional effect) }\end{array}$ & $\begin{array}{r}\text { \% increase in } \\
\text { R\&D-employment } \\
\text { (net effect) }\end{array}$ \\
\hline Research enterprises & -0.48 & -0.24 \\
Private non-profit organisations & 0.44 & 0.97 \\
\hline
\end{tabular}




\section{Conclusion}

The results presented in this report show that certain industries in the private sector are crowded out by both the public sector (government institutions and universities) and a limited number of other industries within the private sector. The crowding-outmechanisms are summarized in table 7.1.

Table 7.1

Crowding-out-mechanisms in the Dutch labour market for R\&D-workers, 1973-1993

\begin{tabular}{ll}
\hline Sector & Crowded out by: \\
\hline Metal industries & Chemical industries \\
& $\begin{array}{l}\text { Universities } \\
\text { Government institutions }\end{array}$ \\
Chemical industries & Metal industries \\
& Agriculture and fisheries \\
& Universities \\
& Government institutions \\
Food and beverage industry & Metal industries \\
& Chemical industries \\
& Universities \\
Transportation, communication and commercial services & Government institutions \\
& Metal industries \\
& Chemical industries \\
Agriculture and fisheries & Government institutions \\
Research enterprises & - \\
Other industries & Private non-profit organisations \\
Universities & - \\
Government institutions & - \\
Private non-profit organisations & - \\
\hline
\end{tabular}

Crowding out between industries within the private sector is important because innovation policy may exhibit a sector bias. With respect to current innovation policy in the Netherlands (see table 1.2), the main source of concern with respect to crowding out between industries within the private sector is the crowding out of chemical industries by agriculture and fisheries. Crowding out by the metal industries and chemical industries is at present not enhanced by Dutch innovation policy. However, with respect to future innovation policy, it is seems sensible to be aware of the crowding-out-effects by the metal industries and the chemical industries. Another effect that warrants attention is the crowding out of research enterprises by private non-profit organisations. 
The results show that when the effect of $R \& D$ expenditure in the public sector on $R \& D$ activities (instead of $R \& D$ expenditure) in the private sector is considered, the evidence is in favour of substitution (crowding out) instead of complementarity for the metal industries, chemical industries, food and beverage industry, and transport, communication and commercial services.

At the same time several industries within the private sector do not suffer from crowding out: agriculture and fisheries, other industries and private non-profit organisations. From a different perspective, there are also a number of industries within the private sector which do not cause crowding out: the food and beverage industry, the transport, communication and services sector, research enterprises and other industries. Since the econometric analysis is restricted to 1973-1993, we cannot draw firm conclusions concerning the effects of the allocation of Dutch innovation policy expenditures in 1999. Nevertheless, the empirical results for 19731993 suggest that the sector bias of current Dutch innovation policy in favour of the food and beverage industry, the transport, communication and commercial services sector and other industries does probably not cause any additional crowding out.

The public sector is not crowded out by the private sector. Within the public sector we did not find crowding out between government institutions and universities. In the first place, individual preferences for the type of research that takes place in government institutions and universities may dampen crowding-out-effects. In the second place, we saw from table 3.1 that government institutions and universities employ an above average number of foreign R\&D-workers, which may further explain the lack of crowding out in the public sector.

From a policy perspective, the results show the importance of international labour mobility of R\&D-workers in compensating crowding-out-effects between sectors of the Dutch economy. An attractive climate for researchers does not only improve the inflow of foreign R\&D-workers, but also stems the outflow of Dutch researchers. Currently, stimulating private R\&D does not seem to have a negative impact on public R\&D as long as government institutions and universities are able to attract sufficient numbers of foreign researchers. Policy measures aimed at facilitating the inflow of foreign R\&D-workers in the private sector might compensate for crowdingout-effects suffered by a number of industries. 


\section{References}

CBS, 1997, Kennis en economie 1997, Voorburg-Heerlen.

Cornet, M., 2001, De maatschappelijke kosten en baten van technologiesubsidies zoals de WBSO, CPB Document No. 008, Den Haag.

David, P.A. \& Hall, B.H., 2000, Heart of darkness: modelling public-private funding interactions inside the R\&D black box, Research Policy Vol. 29 (9), p. 1165-1183.

David, P.A., Hall, B.H. \& Toole, A.E., 2000, Is public R\&D a complement or substitute for private R\&D? A review of the econometric evidence, Research Policy Vol. 29 (4-5), p. 497-529.

Engle, R.F. \& C.W.J. Granger, 1987, Co-integration and error correction: repressentation, estimation and testing, Econometrica 55, p. 251-276.

Goolsbee, A., 1998, Does government R\&D policy mainly benefit scientists and engineers?, American Economic Review, Vol. 88, No. 2, p. 298-302.

Guellec, D. \& van Pottelsberghe, B., 2000, The impact of public R\&D expenditure on business R\&D, STI Working Paper 2000/4, OECD, Paris.

Judge, G.G. \& T. Takayama, 1966, Inequality restrictions in regression analysis, Journal of the American Statistical Association, 61, p. 166-181.

Koninklijk Instituut van Ingenieurs, 1998, Ingenieur en salaris, Den Haag.

Marey, P. \& L. Borghans, 2000, Wage elasticities of the supply of knowledge workers in the Netherlands, ROA-R-2000/6E, Maastricht.

Stern, S., 1999, Do scientists pay to be scientists?, NBER Working Paper 7410.

Stewart, J., 1991, Econometrics, Philip Allan, London.

Trajtenberg, M., 2000, R\&D policy in Israel: an overview and reassessment, NBER Working Paper 7930. 